PRZEGLĄD NAUK HISTORYCZNYCH 2019, R. XVIII, NR 2

http://dx.doi.org/10.18778/1644-857X.18.02.04

\title{
Dzieje i obraz majętności charłupskiej w rękach Walewskich herbu Kolumna w drugiej polowie XVII i XVIII wieku na podstawie inwentarzy dóbr
}

Streszczenie. Wsie Charłupia Wielka, Rowy i Drzązny tworzyły majętność charłupska, która położona w województwie sieradzkim w Rzeczypospolitej Obojga Narodów należała do XVII w. do rodu Świnków, Malskich herbu Nałęcz i Zapolskich herbu Pobóg. Na skutek umów małżeńskich i procesów sądowych dobra te trafiły w ręce Jana Franciszka Walewskiego, stolnika sieradzkiego, i jego żony Konstancji Bogumiły z Zapolskich. W XVIII w. właścicielami dóbr byli kolejni przedstawiciele rodu Walewskich herbu Kolumna: kasztelanowie rozpierscy Jan i Franciszek oraz Jan Nepomucen, chorąży większy sieradzki. Na podstawie zachowanych inwentarzy z końca XVII i XVIII w. można śledzić losy Charłupi Wielkiej, Rowów i Drzązny. Dobra te, które przeżywały okres rozwoju za czasów stolnika sieradzkiego, podupadły na początku XVIII w. z powodu problemów $z$ wierzycielami. Następni właściciele przejęli owe dobra w swoje ręce i podjęli się spłaty zobowiązań. Jednocześnie przez całe stulecie inwestowali w nie, podnosząc ich wartość. Opisy dworu i budynków towarzyszących wskazuja, jak wiele zmieniało się na przestrzeni lat. Dwór stał się siedzibą tej gałęzi Walewskich, a różnorodność zabudowań świadczyła o tym, że właściciele oprócz dochodu $z$ pracy na roli czerpali korzyści finansowe $z$ hodowli owiec czy koni. Ważna kwestia było również zmienne zaludnienie dóbr. Od momentu przezwyciężenia kryzysu z początku XVIII w. liczba ludności zależnej wzrastała, a co za tym szło - rósł również dochód $z$ produkcji rolnej. Losy majętności charłupskiej pokazuja, w jaki sposób szlacheckie majatki położone na terenie województwa sieradzkiego starały się podnieść $z$ okresu zniszczeń $z$ czasów wojny północnej oraz jak radzono sobie $z$ problemem ich zadłużenia i zarządzania w różnych okresach koniunktury gospodarczej.

Słowa kluczowe: inwentarze dóbr w XVIII wieku, szlachta sieradzka w XVIII wieku, własność szlachecka.

* Oddziałowa Komisja Ścigania Zbrodni przeciwko Narodowi Polskiemu w Łodzi, e-mail: m.kobierecki@vp.pl 
$\mathrm{B}$ adanie przeszłości wsi w epoce nowożytnej nie należy do łatwych zadań z powodu niezbyt szerokiej bazy źródłowej. W największym stopniu dotyczy to osad, które należały do rycerstwa czy szlachty. Wyjatkiem jest Charłupia Wielka, leżąca obecnie w gminie Wróblew, na terenie powiatu sieradzkiego w województwie łódzkim, a w czasach nowożytnych w powiecie i województwie sieradzkim Rzeczypospolitej Obojga Narodów. Na podstawie informacji pochodzacych $z$ zachowanych inwentarzy $z$ drugiej połowy XVII i XVIII w. udało się w miarę dokładnie opisać ów świat życia gospodarczego szlacheckich dóbr, utrwalony w tym specyficznym rodzaju źródła historycznego. Do jego uzupełnienia wykorzystałem również informacje odnoszące się do dziejów Charłupi Wielkiej, Rowów i Drzazny, tworzacych majętność charłupska, które w opisywanym okresie znajdowały się w rękach Walewskich herbu Kolumna. Poza kwestia własności dóbr interesowały mnie działania kolejnych właścicieli i pozycja, jaka ta majętność zajmowała w zarządzaniu nieruchomościami w celu podnoszenia dochodów.

W wieku XIV w Charłupi Wielkiej istniała parafia, która należała do dekanatu warckiego, podlegającego archidiakonatowi uniejowskiemu wchodzącemu w skład diecezji gnieźnieńskiej. Kościół parafialny prawdopodobnie ufundowali przedstawiciele rodu Świnków, a ołtarz Malscy herbu Nałęcz ${ }^{1}$. Obie rodziny były blisko związane $\mathrm{z}$ tą miejscowościa, ponieważ $\mathrm{w}$ drugiej połowie XIV stulecia jej właścicielami byli Piotr, kasztelan spicymierski i sieradzki, a później jego synowie Adam oraz Piotr, przedstawiciele pierwszego ze wspomnianych rodów. Następnie majętność charłupską posiadała córka Piotra, Małgorzata, która sprzedała je w 1436 r. kasztelanowi, a później wojewodzie łęczyckiemu, Wojciechowi Malskiemu herbu Nałęcz ${ }^{2}$. Pełnione urzędy oraz kolejne sprawowane funkcje:

${ }^{1}$ Atlas historyczny Polski, t. V (Województwo sieradzkie i województwo łęczyckie $w$ drugiej połowie XVI wieku), red. H. Rutkowski, Warszawa 1998, s. 36, 109; Słownik geograficzny Królestwa Polskiego i innych krajów słowiańskich, t. I, Warszawa 1880, s. 547-548; t. XV, Warszawa 1900, s 300; A. Szymczak, Szlachta sieradzka w XV wieku. Magnifici et generosi, Łódź 1998, s. 354, 398, 417.

${ }^{2}$ Według Stanisława Mariana Zajaczkowskiego Charłupia Wielka z Drzaznami stanowiła przykład rodowego kompleksu majątkowego, który był dziedziczony przez kolejnych właścicieli. Składał się oprócz wymienionych wyżej wsi z zaginionej osady Pawe, Wróblewa, Dąbrówki Zgniłej, Pyszków i części Łosińca. S.M. Zaj ą czkowski, Wielowioskowa własność szlachecka $w$ dawnych ziemiach łęczyckiej $i$ sieradzkiej $w$ drugiej połowie XIII i $w$ XIV w., „Rocznik Łódzki” 1964, t. IX (XII), s. 124; idem, Studia nad wielowioskowa własnościa szlachecka $w$ Łęczyckiem 
w 1440 r. zastępował króla Władysława III na terenie Wielkopolski, a w latach 1443-1447 był starosta generalnym wielkopolskim, potwierdzały wysoka pozycję na dworze Warneńczyka. Trudno ocenić, czy to podniosło znaczenie dworu w Charłupi Wielkiej jako siedziby, ponieważ wojewoda, zajęty wypełnianiem wyznaczonych mu zadań, przez długi czas przebywał poza swymi dobrami ${ }^{3}$ Można domniemywać, że w tym czasie podjęto jakieś prace w dworze lub w jego najbliższej okolicy i być może dowodem na to było pojawienie się w źródłach folwarku we wsi Drzazna ${ }^{4}$ Tym bardziej owe przypuszczenia moga być uzasadnione, ponieważ na przełomie XIV i XV w. klucz charłupski należał do największych w województwie sieradzkim ${ }^{5}$. Po śmierci wojewody łęczyckiego owe dobra pozostały w rodzinie i trafiły ostatecznie w rece syna Wincentego ${ }^{6}$. Natomiast Wojciech, Dobrogost i Wincenty, synowie Wincentego, przejęli majętność po śmierci ojca w 1505 r. ${ }^{7}$

Prawdopodobnie pod koniec XVI w. Charłupia Wielka wraz z pozostałymi wsiami znalazła się w rękach rodu Zapolskich herbu Pobóg. W pierwszej połowie XVII stulecia ich właścicielem był starosta dybowski Stanisław Konstanty Zapolski, natomiast jego córka i Anny Sokołowskiej, Konstancja Bogumiła, poślubiła stolnika sieradzkiego Jana Franciszka Walewskiego herbu Kolumna ${ }^{8}$ i w umowie przedślubnej wyznaczono jej posag w wysokości 24000 złp. Prawdopodobnie w momencie ślubu panny Zapolskiej nie żyli jej rodzice i stad jej opiekunowie, czyli brat Aleksander Ignacy i stolnik brzeski Aleksander Kazimierz Zapolski, zostali obciążeni obowiązkiem wypłacenia owej kwoty. Do tego jednak nie doszło i ostatecznie zobowiazanie do wypłacenia posagu Zapolscy

i Sieradzkiem i jej rola $w$ osadnictwie (od końca XIV do połowy XVI w.), „Kwartalnik Historii Kultury Materialnej” 1966, R. XIV, nr 2, s. 187; idem, Wielowioskowa własność szlachecka $w$ województwie sieradzkim (XV i pierwsza połowa XVI w.), „Rocznik Łódzki” 1973, t. XVIII (XXI), s. 39; A. Szymczak, op. cit., s. 205-208, 225,340 .

${ }^{3}$ A. Szymczak, op. cit., s. 341-342.

4 S.M. Zajaczkowski, Studia..., s. 203.

${ }^{5}$ Id em, Wielowioskowa własność..., s. 29-39; L. Kajzer, Z badań nad budownictwem rezydencjalno-obronnym ziemi łęczyckiej i sieradzkiej $w$ XVI wieku, „Kwartalnik Architektury i Urbanistyki” 1979, t. XXIV, z. 4, s. 373.

${ }^{6}$ A. Szymczak, op. cit., s. 349-350.

7 Ibidem, s. 354-355.

8 Więcej na temat J.F. Walewskiego oraz innych przedstawicieli tego rodu por. M. Kobierecki, Walewscy herbu Kolumna w XVII-XVIII wieku. Genealogia. Majętność. Działalność publiczna, Łódź 2008. 
zapisali na dobrach Charłupia Wielka9. Wynikało to $z$ wygranych przez J.F. Walewskiego procesów o wypłacenie posagu w sądzie grodzkim sieradzkim oraz w Trybunale Koronnym w Piotrkowie. Na tym jednak nie poprzestał i dokonał zajazdu na Charłupię Wielka w 1680 r. ${ }^{10}$

W tym czasie owa wieś wraz z Drząnami, Rowami i folwarkiem Jedynakowskim należała do kolejnego syna nieżyjącego starosty dybowskiego S.K. Zapolskiego, Kazimierza Zygmunta. Przełomem w sprawie okazał się wyrok Trybunału Koronnego z 1685 r., w którym majętność charłupska przypadła J.F. Walewskiemu, a długi ciążące na niej ustalono na kwotę $127925 \mathrm{złp} .^{11}$ Do niej należy wliczyć należność dla Mikołaja Pawłowskiego i jego żony Jadwigi $z$ Kwiatkowic, dzierżawców tych dóbr od 1677 r. ${ }^{12}$ Nowy właściciel porozumiał się $z$ nimi, o czym świadczyła zawarta umowa, w której umieszczono inwentarz dóbr z 1677 r. ${ }^{13}$ Jednak stolnik sieradzki nie wywiązał się ze spłaty należności i M. Pawłowski wraz z synem Andrzejem domagał się $11300 \mathrm{złp} .^{14}$

W takich okolicznościach majętność charłupska znalazła się $\mathrm{w}$ rękach Walewskich h. Kolumna i pozostała w nich do końca istnienia Rzeczypospolitej. Stolnik sieradzki, porządkując kwestie własności, zajął się również obciążeniami finansowi istniejącymi na tych dobrach. Wiadomo, że spłacił 7300 złp. i regularnie w latach 1682-1691 wypłacał kwotę 932 złp. jako prowizję kapitule gnieźnieńskiej od zabezpieczonej sumy 13320 złp., a później przejęli to kolejni właściciele. Podobnie wypłacał prowizję Aleksandrowi i Sebastianowi Czyżewskim od kwoty 2800 złp. i spłacał inne kwoty, np. 700 i 500 złp., kanonikowi sieradzkiemu Stanisławowi Pancerzyńskiemu i nieznanemu $z$ imienia Złoczowskiemu w $1688 \mathrm{r}$. Inni, jak Jan Trepka, który chciał oddania 3000 złp., musieli czekać na wypłatę pieniędzy ${ }^{15}$.

\footnotetext{
${ }^{9}$ Archiwum Państwowe w Łodzi [dalej: APŁ], Archiwum Kazimierza Walewskiego $z$ Tubązina [dalej: Arch. K. Wal.], t. XXXIX, s. 79-80.

10 APE, Arch. K. Wal., t. IV, d. 72; t. XXXIX, s. 79-80.

11 APE, Arch. K. Wal., t. VIII, s. 272-355.

12 Archiwum Główne Akt Dawnych w Warszawie [dalej: AGAD], Księgi sieradzkie grodzkie relacje [dalej: SGRel.] 41, k. 757v; 45, k. 628-629; APŁ, Arch. K. Wal., t. II, dokument 233; t. III, d. 17.

13 AGAD, SGRel. 45, k. 628-633.

14 AGAD, SGRel. 41, k. 757v.

15 AGAD, Księgi sieradzkie grodzkie inskrypcje [dalej: SGInscr.] 184, k. 1036-1040; 186, k. 28v-29, 212v-213, 623v-624, 754v-755; 188, k. 73v-74, 92-92v, 267v-268,
} 
Na tych kilku przykładach problem zadłużenia majętności charłupskiej się nie skończył. Małżeństwo Walewskich porozumiało się z częścią wierzycieli w 1691 r. Częścią owej ugody, która wpisano do ksiag grodzkich, był sporządzony inwentarz. W nim wskazano na wiele nowych bąź wyremontowanych budynków ${ }^{16}$. Jednak w następnym roku zmarł stolnik sieradzki i w dziejach majętności charłupskiej rozpoczął się okres kłopotów, które wpłynęły na jej losy na poczatku kolejnego stulecia. Pierwszym były kwestie spadkowe, ponieważ po śmierci J.F. Walewskiego żyło 11 jego dzieci: trzech synów i osiem córek oraz wnuk Jan ${ }^{17}$. Nie wiadomo, jakie były podziały majatkowe, ale Charłupia Wielka i pozostałe wsie znalazły się przez pewien okres w rękach syna Aleksandra, który zmarł w 1704 r. ${ }^{18}$ Po nim prawdopodobnie dobra trafiły w ręce jego matki, ale nie wiadomo na jak długo. Natomiast w latach 1711-1716 wspomniany wnuk Jan, późniejszy kasztelan rozpierski, porzadkujac kwestie spadkowe, zawarł układ $z$ innymi wnukami stolnika sieradzkiego w dniu 8 czerwca 1716 r. ${ }^{19}$

Na jego mocy przejął prawa dziedziczne do majętności charłupskiej, ale musiał również odzyskać kontrolę nad wsiami. $Z$ tego powodu wystapił na droge sąową przeciwko Bartłomiejowi Cieleckiemu, mężowi Franciszki Walewskiej, córki J.F. Walewskiego, domagając się odszkodowania za poczynione zniszczenia w Charłupi Wielkiej. W konsekwencji pozwany zrzekł się praw do tej wsi 23 czerwca 1716 r. ${ }^{20} \mathrm{~W} 1719$ r. procesował się również z Maciejem Załuskowskim, pełniącym obowiązi starosty sieradzkiego. Przedmiotem konfliktu było korzystanie przez sieradzkich mieszczan $z$ lasów, leżących w granicach Charłupi Wielkiej, co zakończyło się ugodą i wytyczeniem granic między dobrami ${ }^{21}$.

Podobnie ucierpiała wieś Drząny, zajęta przez Wojciecha Krąkowskiego $z$ powodu nieoddania pożyczonych 6000 złp. przez

274; 190, k. 138, 298-298v, 462-462v, 498-498v; 191, k. 267v-268v, 332v-333; APŁ, Arch. K. Wal., t. I, d. 151; t. VIII, s. 272-355.

16 AGAD, SGRel. 55 cz. 1, k. 414-420.

17 Biblioteka Kórnicka PAN, rkps 11267, k. 314; K. Nies iecki, Herbarz Polski, t. IX, Lipsk 1842, s. 216; T. Ży chlińs ki, Złota księga szlachty polskiej, t. IV, Poznań 1882, s. 402, 403.

18 AGAD, SGRel. 61, k. 705-705v.

19 APE, Arch. K. Wal., t. VII, s. 523.

20 AGAD, SGRel. 66, k. 264-264v; APŁ, Arch. K. Wal., t. III, d. 92; t. IV, d. 15.

${ }^{21}$ AGAD, SGInscr. 207, k. 58v-59v; APŁ, Arch. K. Wal., t. IV, d. 23, 25, 27, $28,29,40$. 
Aleksandra Walewskiego i najazdu ze strony braci Gabriela, Piotra i Sebastiana Krąkowskich, synów Władysława, oraz dwunastu napastników. Ostatecznie J. Walewski wypłacił braciom G. i S. Krąkowskim 5600 złp. w 1718 r., realizując wcześniej zawartą ugodę 22 . Natomiast Stefan Kamocki $z$ niejakim Drzewoszewskim, któremu A. Walewski był winien 5880 złp., najechali na wieś Rowy. Tutaj również zawarto porozumienie w 1716 r. o wypłaceniu wierzycielowi 1880 oraz 200 złp. prowizji ${ }^{23}$.

W odzyskaniu wsi tworzących majętność charłupską pomogło małżeństwo kasztelana rozpierskiego J. Walewskiego z Katarzyna, córką Aleksandra Mycielskiego, podsędka ziemskiego, sędziego grodzkiego oraz podstarościego sieradzkiego, i Barbary z Rozdrażewskich, która wniosła w posagu 30400 złp. ${ }^{24}$ Mimo to wiadomo, że pozostały zobowiązania finansowe, zabezpieczone na majętności charłupskiej ${ }^{25}$, ale to nie blokowało np. wydzierżawienia za 1000 złp. browaru charłupskiego Eliaszowi Abramowiczowi w $1718 r{ }^{26}$ Podobnie dziesięć lat później J. Walewski zastawił na trzy lata za 15240 złp. prawo szynkowania piwa w całej majętności oraz plac w Sieradzu Stefanowi Otockiemu ${ }^{27}$.

Kasztelan rozpierski J. Walewski zmarł w 1733 r., ale przed jego śmiercią sporządzono inwentarz majętności charłupskiej w związku $z$ przekazaniem praw spadkowych na syna ${ }^{28}$. Mimo że majętność ucierpiała $z$ powodu pobytu wojska popierającego elektora saskiego podczas walk o tron po śmierci Augusta II ${ }^{29}$, to do końca stulecia nie doświadczyła ona kolejnych zniszczeń. Kolejny kasztelan rozpierski Feliks Walewski wydzierżawiał lub zastawiał Charłupię i pozostałe wsie Maciejowi Cieleckiemu, późniejszemu staroście zgierskiemu ${ }^{30}$. Działo się tak od 1739 r., dotyczyło to rów-

${ }^{22}$ AGAD, SGInscr. 203, k. 222-222v.

${ }^{23}$ AGAD, SGInscr. 201, k. 62v; 202, k. 436v; 204, k. 26; APŁ, Arch. K. Wal., t. IV, d. 14, 26.

${ }^{24}$ M. Kobierecki, op. cit., s. 57.

${ }^{25}$ AGAD SGInscr. 205, k. 102v-103; 207, k. 57, 57-57v; APŁ, Arch. K. Wal., t. I, d. 153; IV, d. 40.

${ }^{26}$ Należność miała być płacona w ratach. APŁ, Arch. K. Wal., t. IV, d. 21.

${ }^{27}$ Zawarty kontrakt przewidywał również odbudowę przez posesora części dóbr w tej majętności. Ibidem, t. IV, d. 33.

28 AGAD, SGInscr. 209, k. 326; APŁ, Arch. K. Wal., t. III, d. 131.

${ }^{29}$ AGAD, SGRel. 92, k. 567-567v.

${ }^{30}$ Wydzierżawiono ją na rok za 4180 złp., a następnie przedłużono na kolejny. W 1754 r. majętność została zastawiona na dwa lata za 14000 złp. APŁ, Arch. K. Wal., t. IV, d. 54, 87. 
nież browaru w Charłupi Wielkiej i placu w Sieradzu, z prawem do produkcji oraz sprzedaży piwa i gorzałki. Jednak w jednym przypadku zmienił dzierżawcę ${ }^{31}$. Natomiast po śmierci F. Walewskiego w 1755 r. ${ }^{32}$ jego żona Krystyna $z$ Rychłowskich, $z$ którą miał synów Jana Nepomucena i Mateusza, po przejęciu kontroli nad majętnością charłupska po śmierci teściowej postanowiła zerwać umowę zastawna $z$ M. Cieleckim, co w konsekwencji naraziło ją na żądanie wypłacenia odszkodowania. Podobnie postapiła $z$ Antonim Glinieckim, zawierając trzyletnią umowę dzierżawną, którą zerwała ${ }^{33}$.

Kolejni właściciele od czasów kasztelana rozpierskiego J. Walewskiego nadal przejmowali majętność charłupską wraz z długami ${ }^{34}$. $Z$ tym również musieli sobie radzić $F$. Walewski czy jego synowie, którzy w momencie śmierci ojca byli niepełnoletni i dopiero w 1777 r. dokonali podziału majątku po ojcu. Nowym właścicielem Charłupi Wielkiej z przyległymi wsiami został J.N. Walewski. Przy tej okazji sporządzono inwentarz i oszacowano wartość tych dóbr na kwotę 95000 złp., ale na mocy umowy znalazły się one przez pewien czas w dzierżawie u brata ${ }^{35}$. Do końca istnienia Rzeczypospolitej majętność charłupska pozostawała w rękach J.N. Walewskiego i jego żony Teresy z Walewskich ${ }^{36}$, która w 1792 r. objęła te dobra w posiadanie jako wdowa. Oboje małżonkowie również wydzierżawiali je różnym użytkownikom ${ }^{37}$.

${ }^{31}$ W 1743 r. za roczna dzierżawę F. Walewski miał otrzymać 1800 złp. (czyli 100 złotych czerwonych, w takiej monecie tę sumę wypłacono), ale po miesiacu zmienił zdanie i podpisał kontrakt z Tobiaszem Jakubowiczem na $1600 \mathrm{złp}$. W 1746 r. zwarł trzecią umowę, opiewająca na sumę 1944 złp. (choć w dokumencie poprawiono ten zapis na 2000 złp.). Ibidem, t. IV, d. 61, 62, 69; t. XL, s. 9v.

32 AGAD, SGInscr. 209, k. 459.

33 Starosta zgierski M. Cielecki domagał się 7000 złp. oraz dodatkowo 1800 złp. Natomiast A. Gliniecki po rocznej dzierżawie wystawił rachunek na kwotę $9165 \mathrm{złp}$. 25 gr. Ibidem 217, k. 466, 466-467, 478, 671, 699-699v; 219, k. 58v, 58v-59; APE, Arch. K. Wal., t. IV, d. 81, 84, 90, 91, 92, 93, 94, 95.

${ }^{34}$ W 1751 r. Józef Starczewski domagał się 13000 złp. Po wyroku Trybunału Koronnego kwota wzrosła do 23600 złp. Natomiast 1000 złp. chcieli bracia Jakub, Wojciech i Zygmunt Raczyńscy. APŁ, Arch. K. Wal., t. IV, d. 65, 73, 77, 78,79, 80.

35 AGAD, SGInscr. 225, k. 398v-399; APŁ, Arch. K. Wal., t. IV, d. 195; t. VII, s. 241-244.

${ }^{36}$ AGAD, SGInscr. 228, k. 31.

37 W latach 1779-1788 wydzierżawiono majętność charłupską Janowi Grądzkiemu za kwoty 24000 i 30000 złp. W 1796 r. Wincenty Grodziecki wydzierżawił je za 21000 złp. AGAD, SGInscr. 226, k. 60; 228, s. 94-95, 95; 230, k. 39-39v, 39v, 39v-40; 234, k. 18v; SGRel. 188, k. 824-834; APŁ, Arch. K. Wal., t. IV, d. 193, 199, 210, 231. 


\section{Dwór i zabudowania gospodarcze}

Z trzech wsi wchodzacych w skład majętności charłupskiej tylko w Charłupi Wielkiej, stanowiącej centrum administracyjne, znajdował się dwór $z$ budynkami o charakterze gospodarczym. Jak wiadomo, w XV w. bywał tutaj wojewoda łęczycki W. Malski, sprawując swoje obowiąki. W kolejnych stuleciach budynek dworu podlegał zapewne różnym przemianom, ale w 1677 r. określono go jako „wielki”. Jednak jego dach wymagał remontu i podbicia go gontami, ale tego nie zrealizowano przez kolejne 14 lat ${ }^{38}$.

W dworskiej sieni znajdowała się spiżarnia ${ }^{39}$, w 1691 r. również piwnica, a nad nią komora, wyposażona w okno oprawne w drewno. Z sieni wchodziło się do izby stołowej wyposażonej w okna, będace w dobrym stanie, oprawione w ołów, na zawiasach i wyposażone $\mathrm{w}$ haczyki, co podkreślało poziom zamożności właściciela. W żadnym $z$ inwentarzy nie podano ich liczby, trudno zatem ocenić wielkość pomieszczenia ${ }^{40}$. W izbie stołowej stał piec, który wymagał remontu, a pod ścianami mieściły się ławy oraz dwa stoły. $\mathrm{Z}$ tego pomieszczenia wchodziło się do pokoju, mającego nieznana liczbę okien wyposażonych identycznie jak w izbie stołowej ${ }^{41}$. Tam znajdował się zielony piec, prawdopodobnie wybudowany już po $1677 \mathrm{r}^{42}$ Do wyposażenia pokoju należały szafa i ławy, stojące przy oknach. W 1677 r. wymieniono komnatę bez kominka ${ }^{43}$, ale w następnych opisach użyto terminów komora lub spiżarnia. Miała ona dwa okna wyposażone w żelazne pręty, w tym jedno oprawione w drewno. Natomiast 14 lat później $z$ owej komory wychodziły

38 AGAD, SGRel. 45, k. 628-633; 55 cz. 1, k. 415-420.

${ }^{39}$ Ilustracje i opisy przedstawiające usytuowanie poszczególnych pomieszczeń w dworach znajdują się w literaturze przedmiotu. Por. A. Wyczański, Uwagi na temat dworu szlacheckiego w Wielkopolsce XVI w., „Kwartalnik Architektury i Urbanistyki” 1979, t. XXIV, z. 4, s. 349, 350-352, 354; id e m, Szlachta polska XVI wieku, Warszawa 2001, s. 72-74.

${ }^{40} \mathrm{~W} 1677$ r. postulowano, by w okna $\mathrm{z}$ kwaterami wstawić szyby. W kolejnym inwentarzu tego problemu już nie było. W XVI w. w większości okna były wyposażone w szyby nie tylko w dworach, lecz także w budynkach o charakterze gospodarczym. Szyby oprawione w ołów stanowiły lepsze wyposażenie niż w drewno. A. Wyczański, Uwagi na temat..., s. 352.

${ }^{41}$ Szczegółowy opis wnętrz pochodził z inwentarza z 1691 r. W 1677 r. owe ołowiane okna były skute $\mathrm{w}$ rogach.

${ }^{42}$ Być może był to piec $z$ kafli polewanych, o czym świadczyłby zielony kolor, ale o tym nie wspomina inwentarz. A. Wyczański, Uwagi na temat..., s. 352.

${ }^{43}$ Trudno też stwierdzić, czy pełniła w tym wypadku funkcję reprezentacyjna, jak stwierdzono w literaturze przedmiotu. A. Wy czańs ki, Szlachta polska..., s. 73. 
na zewnattrz drzwi. $Z$ drugiej strony sieni była izdebka kuchenna $z$ oknami oprawionymi w drzewo, wymagającymi naprawy, w której znajdowała się szafa przeznaczona do chowania naczyń. W $1691 \mathrm{r}$. wspomniano również o przejściu do komory, leżącej przy owej izdebce.

$\mathrm{W}$ obu inwentarzach zwracano uwage na stan drzwi w całym dworze. W 1677 r. wszystkie były na żelaznych zawiasach. Cztery $z$ nich miały zamki, ale tylko do jednego był klucz, pozostałe były niesprawne. W 1691 r. $z$ zewnątrz do sieni wchodziło się przez drzwi na żelaznych zawiasach $z$ zamknięciem i kluczem. Następnie przez kolejne, $z$ klamka, do izby stołowej. Pozostałe były na żelaznych zawiasach. Część $z$ nich miała hebel lub skoble oraz wrzeciądze, czyli grube i krótkie łańcuchy ${ }^{44}$. Natomiast drzwi prowadzące $z$ sieni do komory, leżącej nad piwnica, miały sprawne zamknięcie $z$ kluczem. Inne, prowadzace $z$ komory na zewnatrz, były jeszcze wyposażone w drewnianą zaporę ${ }^{45}$.

W roku 1716 ów wielki dwór w Charłupi Wielkiej znajdował się w złym stanie, częściowo zawalony i pokryty snopkami, przypominał raczej kmieca chałupę niż szlachecką rezydencję. Do zamieszkania nadawała się wymagająca remontu izba $z$ czterema oknami wypełnionymi błonami $z$ piecem oraz kominem. Kolejnymi pomieszczeniami były komora bez okien i mały pokój z zielonym piecem, kominem oraz oknem oprawionym w ołów ${ }^{46}$. Natomiast 12 lat później w Charłupi Wielkiej stał już nowy dwór składający się z dwu izb, pokoju, alkierza i dwóch komór. Izba stołowa miała cztery okna oprawione w ołów, co odróżniało ją od czeladnej $z$ dwoma oknami oprawionymi w drzewo. Poza tym w izbie stołowej i pokoju $z$ dwoma oknami mieściły się piece $z$ kominami oraz dwie szafy. Trzecia $\mathrm{w}$ alkierzu była wielka $z$ czterema szufladami. $Z$ drugiej strony dworu znajdowały się pomieszczenia o charakterze gospodarczym: izba czeladna $z$ dużym stołem, komora, a w sieni pod schodami prowadzącymi na strych komórka ${ }^{47}$. W ko-

${ }^{44}$ Skobel był wbity w futrynę, a wrzeciądz był przybity do drzwi. Za pomoca kłódki można było zamknać drzwi. Z. Gloger, Budownictwo drzewne $i$ wyroby $z$ drzewa w dawnej Polsce, t. I, Warszawa 1907, s. 259, 302.

${ }^{45} \mathrm{~W}$ inwentarzach wymienia się jedynie żelazne części, jakich użyto do mocowania drzwi bądź sposobu ich zamykania. Żadnych innych informacji nie podano. AGAD, SGRel. 45, k. 628-633; 55 cz. 1, k. 415-420; A. Wyczański, Uwagi na temat..., s. 352-353.

46 APE, Arch. K. Wal., t. IV, d. 13.

47 Ibidem, t. IV, d. 35. 
lejny opisie $z$ roku 1732 wymieniono, że dwór składał się z trzech izb wyposażonych w okna, $z$ pieca i spiżarni ${ }^{48}$.

Trochę więcej informacji zawierał inwentarz sporządzony w 1739 r. Wymieniono sień, w której znajdowała się apteczka, czyli osobna izdebka, miejsce na przechowywanie „korzeni kuchennych, przysmaków, konfitur, soków, wódek, likworów i lekarstw domowych"49. Na zachód od niej były dwie izby i dwa pokoje, jednak te ostatnie wyłączono $z$ opisu, ponieważ należały do ówczesnego właściciela F. Walewskiego i nie były przedmiotem dzierżawy. Po drugiej stronie znajdowała się izba i dwie komory. W porównaniu z 1728 r. w opisie dworu pojawiły się izba i komórka. Być może przekwalifikowano alkierz na jeden $z$ pokoi. Wymieniono także trzy kominy, w tym jeden „polepiony”, oraz trzy piece, w tym dwa zielone. Poza tym były drzwi z zamkiem wrocławskim, kredens $z$ drzwiczkami i dwiema szufladami, dębowy stół $z$ szufladą oraz szafa i ława w izbie czeladnej ${ }^{50}$.

W 1739 r. po raz ostatni użyto stwierdzenia, że dwór był nowy. Sześć lat później przeszedł rozbudowę, która kosztowała 1759 złp. 19 gr. Przede wszystkim pojawił się ganek $z$ czterema słupami i jednym oknem, $z$ którego wchodziło się do sieni, gdzie były dwa okna, a pod nimi ławy i stół. Następnie była kuchnia, izba wyposażona w dwa szklane okna określane jako „taflowe”, składajace się $z$ małych tafli szkła oprawionych w drzewo, oraz komora i spiżarnia. Po zachodniej stronie sieni znajdowała się nieopisana izba, którą wyłączono jako niepodlegająca umowie dzierżawy. $Z$ ganku wchodziło się przez sionkę do przybudowanych trzech pokoi, do jednego $z$ nich wiodły podwójne drzwi, a po lewej znajdowała się apteczka. Każdy z nich został wyposażony w jedno „taflowe” okno. Dobudowana część miała nowy dach, a pokoje wyposażono w posadzkę, natomiast pokrycie nad starszą częścią wyremontowano. W całym budynku znajdowały się trzy kominy, w tym jeden wniesiony w dobudowanej części ${ }^{51}$.

Tak wyglądał dwór w Charłupi Wielkiej w połowie XVIII w. Niewiele zmian zaszło w jego bryle do 1777 r., gdy opisano go po raz kolejny. W porównaniu $z$ poprzednim opisem można zauważyć tylko kilka różnic, m.in. nie wymieniono sionki, opisano pokój wcze-

\footnotetext{
48 Ibidem, t. IV, d. 43.

49 Z. Gloger, Encyklopedia staropolska ilustrowana, t. I, Warszawa 1900, s. 57.

50 APE, Arch. K. Wal., t. IV, d. 55.

${ }^{51}$ Ibidem, t. IV, d. 66, 93.
} 
śniej wyłączony $z$ inwentarza i pojawił się ganek $z$ drugiej strony domu $z$ wyjściem do sadu. Oprócz takiego samego rozkładu zaszły duże różnice pod względem ich wyposażenia. Pokoje miały podłogi „w tabulatury”, czyli pewien rodzaj parkietu, a nie tarcic ${ }^{52}$. Natomiast ściany były obite zielonym suknem czy adamaszkiem „w pasy”. Jak twierdził Jędrzej Kitowicz, opisując czasy saskie, tego rodzaju obicia ścian były norma, szczególnie w siedzibach magnackich pokoje ozdabiano w jednym kolorze, od którego czerpano nazwy ${ }^{53}$. W dworze charłupskim tylko jeden $z$ pokoi miał cztery okna "taflowe” oprawione w drzewo, reszta miała po jednym. Ponadto były piece: zielony $z$ kominem i murowany piecyk w izbie oraz biały $z$ murowanym kominem w pokoju, kaflowy w izbie czeladnej oraz malowane w innych pomieszczeniach ${ }^{54}$.

Dwór w Charłupi Wielkiej znajdował się poza wsią, jednak nie miał dodatkowych walorów obronnych w postaci położenia na wzniesieniu. Spełniał, tak jak większość wzniesionych na terenie Wielkopolski, funkcję mieszkalno-gospodarczą. Niewątpliwie bliskość budynków o charakterze gospodarczym obniżała jego rangę ${ }^{55}$. Jednak w XVIII stuleciu wyposażenie, o które zadbali kolejni właścicieli, świadczyło jednoznacznie, że traktowali ów dwór jako ich siedzibę i rezydencję, skąd zarządzali majątkiem, ale również prowadzili życie towarzyskie i działalność publiczną.

Otoczenie dworu zmieniało się już od 1677 r., gdy rozebrano jeden ze starszych budynków, aby podwórze otoczyć parkanem. Następnie ustawiono płoty, a $z$ wsi do dworu prowadziła droga obok, której stały zabudowania dworskie. Na drodze znajdowała się brama $z$ wrotami i furta na drewnianych biegunach ${ }^{56}$

${ }^{52}$ W. Łoziński, Życie polskie $w$ dawnych wiekach (wiek XVI-XVIII), Jerozolima 1946, s. 79.

${ }^{53}$ W ten sposób nazywano pokoje „zielonym” czy „żółtym”. Według J. Kitowicza obicie pokojów adamaszkiem było „najparadniejsze”, choć może w tym okresie nie najmodniejsze, nad czym ubolewał. Natomiast Bohdan Baranowski, który badał opisy dwór szlacheckich w województwie łęczyckim, zwracał uwagę, że tego rodzaju ozdoby na ścianach zdarzały się tylko w zamożniejszych dworach szlacheckich i przeważnie w reprezentacyjnym pomieszczeniu. J. Ki tow ic z, Opis obyczajów za Augusta III, Warszawa 1985, s. 269; B. Bara nowski, Gospodarstwo chłopskie i folwarczne we wschodniej Wielkopolsce w XVIII wieku, Warszawa 1958, s. 99.

${ }^{54}$ APŁ, Arch. K. Wal., t. VII, d. 225-239.

55 A. Wyczański, Uwagi na temat..., s. 348; idem, Szlachta polska..., s. 72.

56 Polegało ono na tym, że do pionowo umocowanego słupa, czopa, przymocowywano wrota lub drzwi i w ten sposób stawał się on ich nierozerwalna częścią. Na górze ów słup, czop był montowany w wyżłobiony miejscu w kawałku drzewa, 
wyposażone w kunę, czyli uchwyt, za pomoca którego można było ja otworzyć, oraz żelazne heble. Za nią droga prowadziła przez most na dziedziniec, a za nim była samborza, która po remoncie liczyła cztery komory znajdujące się na parterze ${ }^{57}$. Nie wymieniono okien, a tylko dwoje drzwi na zawiasach $z$ wrzeciądzami i skoblami. Natomiast wrota miały dwa żelazne zamki, co może świadczyć o poczuciu zagrożenia ze strony szlacheckich właścicieli. Kilkanaście lat później wspomniano, że właśnie wybudowano jej część wschodnią. Był również ganek, izba i trzy komory, w których były okna oprawione w ołów oraz drzwi $z$ wrzeciądzami i skoblami. Sama samborza była pokryta nowymi gontami ${ }^{58}$. Od tego momentu jej stan ulegał zapewne pogorszeniu, o czym świadczył lakoniczny zapis z 1716 r., że prowadziły do niej „wrota uliczne” i znajdowały się w niej trzy izby bez okien ${ }^{59}$.

Istnienie samborzy w Charłupi Wielkiej to być może reakcja na zagrożenie ze strony nieopłaconych grup żołnierskich bądź maruderów w okresie „wieku wojen”, tym bardziej że nic nie wiadomo o jej istnieniu wcześniej ${ }^{60}$. Należy jednak podkreślić, że w tym czasie samborza pełniła bardziej funkcje budynku użytkowego ${ }^{61}$.

W opisie z 1728 r. nie wymieniono już samborzy, a do dworu prowadził nowy gościniec, który nie był jeszcze wykończony. Podwórze było otoczone prawdopodobnie płotem ze sztachet i brama wyposażona w trzy nowe wrota. Natomiast przed dworem mieściła się

który został specjalnie do tego przymocowany. Podobnie na dole słupek obracał się w wyżłobieniu podwaliny, ewentualnie w dostawionym specjalnie do tego celu pieńku drzewa. B. Klim e k, Zabytkowa stolarka okienna i drzwiowa drewnianych chałup i zabudowy gospodarskiej na Lubelszczyźnie - wybrane przykłady z Muzeum Wsi Lubelskiej, „Budownictwo i Architektura” 2015, t. XIV (III), s. 199.

57 Jak podaje słownik, termin ten oznaczał wieżę obronną umieszczona nad bramą wjazdowa. Już w XVI w. na terenie Wielkopolski samborza pełniła inne funkcje niż obronne. W. Łoziński, op. cit., s. 63; Słownik staropolski, red. S. Urbańczyk, t. VIII, z. 2, Wrocław 1978, s. 118; A. Wyczański, Uwagi na temat..., s. 348.

$58 \mathrm{~W}$ przypadku samborzy można zauważyć, że była to budowla piętrowa. AGAD, SGRel. 45, k. 628-633; 55 cz. 1, k. 415-420. A. Wyczański, Uwagi na temat..., s. 354.

59 APE, Arch. K. Wal., t. IV, d. 13.

${ }^{60}$ Por. S.M. Zajączkow ski, Własność rycerska $w$ dawnych ziemiach łęczyckiej i sieradzkiej do połowy XIII w., „Rocznik Łódzki” 1961, t. IV (VII), s. 139-169; i d e m, Uwagi nad osadnictwem dawnych ziem łęczyckiej i sieradzkiej (do przełomu XI i XII w.), „Rocznik Łódzki” 1964, t. IX (XII), s. 165-198.

${ }^{61}$ Według B. Baranowskiego samborze zdarzały się w XVIII w. na obszarze Łęczyckiego coraz rzadziej. B. Baranowski, op. cit., s. 94; A. Wyczański, Szlachta polska..., s. 72 . 
nowa piwnica62 . Być może w czasie przebudowy podwórza wykorzystano nowo usypaną górkę w 1716 r., w której umieszczono dwa schowki: górny i dolny z zamknięciem ${ }^{63}$. W 1732 r. wspomina się jedynie o nowej oficynie, w której znalazły się sień, izba i komora. Poza tym brakuje dokładnych informacji o rozmieszczeniu budynków przed dworem ${ }^{64}$. Siedem lat później dwór był otoczony ogrodzeniem $z$ brama, przez którą można było się dostać do browaru ${ }^{65}$. Niewiele zmieniło się w kolejnych latach. Nadal istniało ogrodzenie ze sztachet. Natomiast w drugiej połowie XVIII w. na przeciwko dworu istniał skarbiec, który nazywano również kaplicą. Był to pokój z oknem i $z$ dwoma "sklepikami dylowanymi”, czyli stropami opartymi na drewnianych balach ${ }^{66}$.

Poza dworem i jego najbliższym otoczeniem znajdowały się różne zabudowania gospodarcze ${ }^{67}$, co było charakterystyczne dla dworów szlacheckich położonych $\mathrm{w}$ Wielkopolsce od XVI w. ${ }^{68}$ Wśród nich wymienić można ozdownię 69 , browar i mielcuch oraz gorzelnię, czyli budynki służące do produkcji piwa i gorzałki. W 1677 r. istniała „szkudłowana” ozdownia wraz z komora, gdzie były drzwi do sypania słodu, wraz $z$ dwojgiem drzwi na żelaznych zawiasach ze skoblami. Na górze suszono słód. Był również mielcuch bez dachu, drzwi i okien. W zamian za to znajdowały się tutaj dwie kadzie, dwa przycierki, kocioł, beczki i garniec gorzałczany. W 1691 r. nie wymieniono tego budynku, natomiast istniał browar, do którego prowadziła droga $z$ dworu, składający się z sieni i dwu izb oraz "góry”. Do sieni wchodziło się przez drzwi na żelaznych zawiasach. Tych było razem pięć, ale tylko jedne były na drewnianych biegunach. W sieni oraz w izbach browaru znajdowały się okna, w dobrym stanie, oprawione $\mathrm{w}$ drewno, piece i kominy. Cały budynek był pokryty

62 APŁ, Arch. K. Wal., t. IV, d. 35.

${ }^{63}$ Ibidem, t. IV, d. 13.

${ }^{64}$ Ibidem, t. IV, d. 43.

65 Ibidem, t. IV, d. 55.

66 „Dyl to samo tu znaczy co bal, z czterech stron piła obdarty”. Ibidem, t. VII, d. 225-239; Z. Glog e r, Budownictwo drzewne..., t. I, s. 379.

67 Na temat roli poszczególnych budowli o charakterze gospodarczym, istniejących wokół szlacheckiego dworu pisał B. Baranowski. Praca ta dotyczy majątków szlacheckich w województwie łęczyckim. B. Bara now ski, op. cit., s. 90-95.

68 A. Wyczański, Uwagi na temat..., s. 348.

69 W ozdowni znajdował się słód, który podlegał suszeniu, dzięki paleniu w piecu. Ten proces nazywał się ozdowaniem - stąd nazwa miejsca, gdzie to robiono. Z. Glog er, Budownictwo drzewne..., t. I, s. 290. 
w części szkutami i snopkami. Należy podkreślić to, że w tym samym czasie wybudowano nową studnię, którą ocembrowano ${ }^{70}$.

$\mathrm{Na}$ poczattku XVIII w. budynek browaru nie był w najlepszym stanie. Wymagał remontu, podobnie jak piece w obu izbach, okno w jednej $z$ nich, gdzie „słody robia”, a poza tym brakowało komina. W drugiej izbie, majacej dwa okna oprawione w drzewo, znajdował się kominek i urządzenia do produkcji piwa, jak mały kociołek, który był naprawiany i dwie dobre kadzie ${ }^{71}$. Sytuacja częściowo poprawiła się w 1728 r., gdy stał już nowy browar pokryty gontem $z$ dwiema izbami oraz komorami wyposażonymi w okna oprawione w drzewo. Budynek browaru miał dwie kondygnacje, a w jego pobliżu znajdowała się ocembrowana studnia. W opisach $z$ lat 1739 i 1777 zmieniło się niewiele, nie liczac powstania trzeciej izby kosztem jednej $z$ komór. Poza tym w drugiej połowie XVIII w. były jeszcze sień i ust, czyli suszarnia słodowa, którą nazywano również izbą słodowa ${ }^{72}$.

Po raz pierwszy o gorzelni wspomniano w 1716 r. Była wyposażona w piec bez komina i miała garniec do „palenia gorzałki”. Szesnaście lat później stał już nowy budynek gorzelni składający się $z$ sieni i izby $z$ oknem oprawionym w ołów. W niej znajdował się piec $z$ kominem oraz przyrządy do produkcji gorzałki. Opis tej gorzelni pojawiał się trzykrotnie w latach 1754, 1755 i $1777^{73}$.

Budynek ozdowni pominięto w opisie z $1716 \mathrm{r}$., ale w następnym uznano go za stary. W latach 1728-1732 wybudowano nowy browar $z$ ozdownią, która wyposażono w piec i po raz kolejny wymieniono ja tylko w $1755 \mathrm{r}^{74}$

Innymi budynkami gospodarczymi, których zadania wiązały się z obsługa mieszkańców dworu, były: piekarnia, serniki czy kuchnia. W 1677 r. pierwszy $z$ nich stał przy świńskiej oborze i miał drzwi wejściowe na drewnianych biegunach, a drewniane okna i piec wymagały naprawy ${ }^{75}$. Do $1691 \mathrm{r}$. wyremontowano piekarnię, pokrywając ją starymi i nowymi snopkami. Dobudowano, oprócz sieni, wielkiej izby, nową izbę $z$ piecem i kominem oraz komore izdebną, w której było okienko oprawione w drewno, podobnie jak wymagające naprawy okna w pozostałych izbach. Budynek wypo-

\footnotetext{
70 AGAD, SGRel. 45, k. 630-633; 55 cz. 1, k. 415-420.

71 APE, Arch. K. Wal., t. IV, d. 13.

72 Ibidem, t. IV, d. 35, 43, 55; t. VII, d. 225-239.

73 Ibidem, t. IV, d. 43, 88, 93.

${ }^{74}$ Ibidem, t. IV, d. 35, 43, 88.

75 AGAD, SGRel. 45, k. 630-633.
} 
sażono w drzwi na żelaznych zawiasach ze skoblami $z$ wyjątkiem wejściowych i prowadzacych $z$ jednej $z$ komór na zewnątrz, które były na drewnianych biegunach ${ }^{76}$.

W tym samym czasie pojawił się nowy budynek nazywany sernikiem, stojacy przy piekarni na dwu słupach. Drugi, podbity szkudłami, do którego prowadziły drzwi na żelaznych zawiasach, znajdował się bliżej dworu. W nich suszono sery ${ }^{77}$.

Natomiast kuchnia jako odrębny budynek nie pojawiła się prawie w żadnym okresie $z$ wyjątkiem 1716 r. i wtedy wymagała odbudowy, ale została prawdopodobnie zburzona ${ }^{78}$.

Poza tym były obory, stodoły, stajnie, owczarnie, chlewy czy spichlerze. W 1677 r. stały trzy chlewy, obory i owczarnia, obie w złym stanie, oraz leżąca przy stodołach chlewnia, pokryta snopkami. Małżeństwo Walewskich wyremontowało oborę, znajdowały się „w niey toki, drabiny dla bydła i most nowo położony”. Pokryta była nowymi i starymi snopkami. Ponadto wybudowali nowa owczarnię, do której prowadziły wrota na drewnianych biegunach. Poza tym wymieniono chlewy i pojawił się nowy kurnik pokryty snopkami ${ }^{79}$. Stan obór po raz kolejny opisano w 1728 r. i to razem $z$ chlewikami, które były ustawione w kwadrat wraz ze stajniami. W 1739 r. uznano, że wymagały one remontu, ale nie wiadomo, czy go przeprowadzono, ponieważ w 1754 r. istniały już nowe. Ponad 20 lat później znowu rozpoczęto budowę nowych obór ${ }^{80}$.

Liczba stodół stojących w pobliżu dworu wahała się od trzech do pięciu. W drugiej połowie XVII w. było ich trzy i łącznie miały pięć „boiowisk”. Niewatpliwie do 1691 r. wyremontowano je i zostały wyposażone w 10 wrót na żelaznych kunach $z$ czterema zamkami i kluczami, w najmniejszej była również kłódka $z$ kluczem ${ }^{81}$. Na początku XVIII w. tylko jedna $z$ czterech była w dobrym stanie. Dwie największe o dwu klepiskach wymagały natychmiastowego remontu. W 1728 r. było ich pięć, ale później już tylko trzy, w tym dwie duże i nowe ${ }^{82}$.

76 Ibidem, 55 cz. 1, k. 415-420.

77 Ściany w sernikach budowano $z$ desek lub gęsto uplecionej wikliny i wierzbowych gałęzi. Miał słomiany daszek. Ibidem, 55 cz. 1, k. 415-420. Por. Z. G1oger, Budownictwo drzewne..., t. I, s. 271.

78 APŁ, Arch. K. Wal., t. IV, d. 13.

79 AGAD, SGRel. 45, k. 630-633; 55 cz. 1, k. 415-420.

80 APE, Arch. K. Wal., t. IV, d. 35, 43, 55, 88; t. VII, d. 225-239.

81 AGAD, SGRel. 45, k. 630-633; 55 cz. 1, k. 415-420.

82 APE, Arch. K. Wal., t. IV, d. 13, 35, 43, 55, 88; t. VII, d. 225-239. 
Nie wiadomo, ile było stajni w 1677 r., ale wymagały one nowego pokrycia dachu. W $1691 \mathrm{r}$. wymieniono jedynie jedna i jej stan nie uległ zmianie. Zalecano wręcz jej wyburzenie i wybudowanie nowej. Podobnie było w przypadku wozowni, mającej wrota na drewnianych biegunach ${ }^{83}$. Natomiast w latach $1716-1732 \mathrm{w}$ inwentarzach wymieniono jedna stajnię, która była w dobrym stanie. Znajdowała się ona przy wjeździe na podwórze, przy którym był położony dwór ${ }^{84}$. W 1739 r. okazało się, że oprócz jednej w złym stanie była kolejna przy stodołach oraz nowa stajenka. W 1754 r. zlokalizowano ja przy dwu spichlerzach, które były oddalone od dworu. Była również niezlokalizowana stajnia $z$ komórką oraz inna położona przy wyjściu $z$ ogrodu, do której droga prowadziła przez mostek. Znajdowały się tam dwie komórki i trzy miejsca dla koni. Obok niej była, niepojawiająca się we wcześniejszych opisach, wozownia $z$ dwojgiem wrót. Prawdopodobnie F. Walewski zaczął hodować konie, co potwierdza istnienie kolejnego budynku zwanego kobylarnią. To w nim znajdowały się źrebne klacze bądź ze źrebięta$\mathrm{mi}^{85}$. Niewatpliwie pojawienie się tego rodzaju budynków wiązało się $z$ funkcja regimentarza partii wielkopolskiej, która sprawował od listopada 1745 r. do 1749 r. oraz w późniejszym okresie ${ }^{86}$. Natomiast w opisie z 1777 r. pojawiły się tylko obie stajnie leżące obok wozowni ${ }^{87}$.

Po roku 1677 Walewscy wybudowali nową owczarnię pokrytą snopkami, do której prowadziły drzwi na drewnianych biegunach „Z kuną żelazna y skoblami"88. Na początku XVIII w. hodowano w niej 73 owce i 27 jagniąt, choć jej stan nie był dobry. Wybudowano nowa, istniejaca do połowy XVIII w., gdy F. Walewski zlecił postawienie kolejnej 30 sierpnia $1751 \mathrm{r}$. Mistrz ciesielski Ignacy Grygier miał wykonać to zadanie za kwotę 150 złp. Oprócz tego pracownicy mieli otrzymywać wynagrodzenie w naturze, m.in. w życie, pszenicy, soli oraz piwie. Budowa trwała prawdopodobnie rok, bo ostatni

83 AGAD, SGRel. 45, k. 630-633; 55 cz. 1, k. 416v.

${ }^{84}$ Taki opis zawarto w inwentarzu z $1716 \mathrm{r}$. W następnych opisach nie precyzowano, gdzie owa stajnia była położona. APŁ, Arch. K. Wal., t. IV, d. 13, 35, 43.

85 Z. Gloger, Budownictwo drzewne..., t. II, Warszawa 1907, s. 103.

86 T. Cie siels ki, Armia koronna w czasach Augusta III, Warszawa 2009, s. 175, 177, 178.

87 APŁ, Arch. K. Wal., t. IV, d. 55, 88, 93; t. VII, d. 225-239.

88 AGAD, SGRel. 45, k. 630-633; 55 cz. 1, k. 416. 
rachunek pochodził z 29 kwietnia 1752 r. Przetrwała do lat siedemdziesiątych XVIII w. ${ }^{89}$ Hodowano również świnie, o czym świadczy wymienienie czterech małych chlewików w 1716 r., a 23 lata później pięciu chlewów. Liczba ta rosła i w 1754 r. osiagnęła 11, dodatkowo wymieniono „karmnik dla wieprzów”. Nie wiadomo, czy $\mathrm{w}$ takiej liczbie nadal istniały w kolejnych latach. W 1777 r. stwierdzono jedynie, że były nowe chlewy wraz $z$ „karmnikiem” 90 .

W 1677 r. wspomniano spichlerz, który miał dwie kondygnacje i dobre zamknięcie w postaci kłódki. Dzięki staraniom J.F. Walewskiego i jego żony budynek został „wyważony przyciesiami podwleczony y naprawiony". Wchodziło się do niego przez górna kondygnację, do której prowadziły drzwi na żelaznych zawiasach. Natomiast drzwi „do dolnego zchowania y piwnicz” były na drewnianych biegunach. Mimo że był pokryty częściowo nowymi szkudłami, to wymagał dalszej naprawy dachu. Postawiono kolejny spichlerz, pokryty snopkami, z trzema drzwiami zrobionymi z żerdzi na żelaznych zawiasach ${ }^{91}$. Po raz kolejny o spichlerzu, leżącym przy stajence i majacym troje drzwi, wspomniano w 1728 r. Przetrwal w dobrym stanie kilkanaście lat. Między 1739 r. a 1754 r. dobudowano kolejny w pobliżu starszego. Jednak po ponad 20 latach został tylko jeden ${ }^{92}$.

Inną ważną częścią owych dóbr nieruchomych w Charłupi Wielkiej był folwark. W latach 1677-1691 nazywano go Jedynakowski. Był otoczony płotami i żerdziami. W inwentarzach pod tym właśnie terminem opisano budynek, który składał się z sieni, izby, komory izdebnej oraz komory, pokryty snopkami. Do sieni prowadziły drzwi na drewnianych biegunach, podobnie jak do komory. Pozostałe dwoje drzwi było na żelaznych zawiasach. W izbie było troje drewnianych okien oraz piec do naprawy. Poza nim był również spichlerz z drzwiami na żelaznych zawiasach, który wymagał remontu i nowego pokrycia dachu, podobnie jak zniszczona stodoła, obora i chlewy. W skład folwarku wchodził jeszcze dwór należący do Zapolskich, chałupy, owczarnie czy stodoła o dwu klepiskach ${ }^{93}$.

\footnotetext{
89 APŁ, Arch. K. Wal., t. IV, d. 13, 35, 43, 55, 76, 88, 93; t. VII, d. 225-239.

90 Ibidem, t. IV, d. 13, 35, 43, 55, 88, 93; t. VII, d. 225-239.

91 AGAD, SGRel. 45, k. 630-633; 55 cz. 1, k. 416-416v.

92 APE, Arch. K. Wal., t. IV, d. 35, 43, 55, 88; t. VII, d. 225-239.

93 AGAD, SGRel. 45, k. 633; 55 cz. 1, k. 416v-417.
} 
Kolejny opis z 1716 r. informował jedynie o budynku, który miał dwie izby i trzy komory. Ściany były w złym stanie, podobnie jak dwa piece i kominy. Kolejne opisy z lat 1754 i 1777 wskazywały na inny budynek, składający się $z$ dwóch izb rozmieszczonych po obu stronach sieni, dwu komór i kuchenki. Każda $z$ izb była wyposażona w piec $z$ kominem, a w jednym $z$ nich wypiekano chleb. W innej zaś znajdowała się szafa $z$ trzema półkami. Stwierdzono także, że okna były w dobrym stanie poza jednym, w izbie czeladnej, gdzie brakowało trzech szyb ${ }^{94}$.

W opisach pojawiały się także inne budynki. W 1691 r. przy drodze prowadzacej $z$ dworu do browaru, niedaleko mostku, stał jednoizbowy budynek, potrzebujący „wyważenia i przyciesi, podwleczenia y nakrycia" $z$ drzwiami na żelaznych zawiasach. Dwoje okien oprawionych w drzewo $z$ szybami wymagały naprawy ${ }^{95}$. Dwa małe, jednoizbowe budynki $z$ piecami były niedaleko sadzawek. $Z$ opisu z 1739 r. wiadomo, że jeden $z$ nich miał dwa okna, a drugi jedno. Prawdopodobnie rozbudowano je, ponieważ w 1754 r. jeden $z$ nich oprócz izby $z$ dwoma oknami miał sień i komorę. W drugim mieszkał ogrodnik. Wtedy po raz pierwszy stwierdzono, że za dworem znajdował się ogrodzony ogród. W 1754 r. wymieniono ponadto pięć kurników, plewnię ${ }^{96}$, która pojawiła się w 1691 r. ${ }^{97}$ Wspomina się o nich także 23 lata później. Natomiast między budynkiem folwarku a dworem były cztery stawy hodowlane. Wymieniono domy rzemieślników, w tym kowala wraz z kuźnią, które przetrwały do 1777 r. To właśnie wtedy wspomniano również o folwarku w Rowach, gdzie miały się znajdować stodoła o jednym klepisku, spichlerzyk, obora, plewnia, owczarnia i chałupka dla owczarza ${ }^{98}$.

\section{Poddani i ich powinności}

Lektura zachowanych do dziś inwentarzy majętności charłupskiej pozwala również na odtworzenie zaludnienia i przedstawienie struktury zawodowej mieszkańców. Informacje na ten temat zostały przedstawione w Tabeli 1, w której wymieniono kmieci, za-

\footnotetext{
${ }^{94}$ APŁ, Arch. K. Wal., t. IV, d. 13, 88, 93; t. VII, d. 225-239.

${ }^{95}$ AGAD, SGRel. 55 cz. 1, k. 415v.

96 Plewnia to pomieszczenie na plewy, szopa. Słownik staropolski, red. S. Urbańczyk, t. VI, z. 2, Wrocław-Warszawa-Kraków 1970, s. 152.

${ }_{97}$ Była pokryta snopkami i miała drzwi na drewnianych biegunach. AGAD, SGRel. 55 cz. 1, k. 416v.

98 APE, Arch. K. Wal., t. IV, d. 55, 88; t. VII, d. 225-239.
} 
grodników, komorników $z$ komornicami ${ }^{99}$ oraz pojawiających się w niektórych inwentarzach chałupników $z$ chałupnicami ${ }^{100}$. Poza tym w samej majętności mieszkali rzemieślnicy wykonujący swoje usługi dla okolicznej ludności lub dworu ${ }^{101}$. Natomiast brakuje informacji o kobietach, dzieciach czy osobach w podeszłym wieku bądź niezdolnych do pracy.

Zebrane dane umieszczone w tabeli 1 jednoznacznie wskazują na "centrum" majętności, czyli Charłupię Wielka, w której żyła i pracowała ponad połowa $z$ wymienianych $\mathrm{w}$ spisach poddanych. $\mathrm{Z}$ inwentarza sporządzonego w $1691 \mathrm{r}$. jednoznacznie wynika, że w 11 przypadkach Walewscy odbudowali, wyremontowali bądź wybudowali domy, stodoły czy obory kmieciom $z$ tej wsi. W następnych dziesięciu skorzystali $z$ tego kmiecie Drzaznej, a w Rowach wzniesiono jedynie izbę i stodołę. Ten poważny wysiłek organizacyjny właścicieli najlepiej potwierdziła uwaga umieszczona w tym inwentarzu, że tylko jedna chałupa kmieca w całej majętności wymagała naprawy. Podobna sytuacja zaszła w przypadku budynków zamieszkałych i użytkowanych przez zagrodników. Dla nich wyremontowano bąź wybudowano domy, izby, stodoły czy obory w 13 zagrodach w całych dobrach.

Po okresie inwestycyjnym majętność charłupska doświadczyła wielu negatywnych zjawisk, które przyczyniły się do jej gospodarczej zapaści. Zniszczeniom różnego rodzaju budynków towarzyszyło obniżenie się liczby poddanych. Jedna $z$ odpowiedzialnych za to osób był wspomniany posesor Charłupi Wielkiej, zięć stolnika sieradzkiego, B. Cielecki. To jego oskarżano o sprowadzenia wojska, co spowodowało ucieczkę wielu poddanych, uprowadzenie do swoich dóbr 16 kmieci, 8 półrolników i 9 zagrodników oraz działania, które doprowadziły do zniszczenia stawów i grobli, wyłowienia ryb. $\mathrm{Z}$ powodu braku młynarzy nie pracowało również 13 młynów ${ }^{102}$.

99 Grupa komorników była uznawana za przydatna i związana z kmieciami lub dworem. Pracowali dla kmieci, ale również na pańskim polu, wypełniając pańszczyznę własna lub w zastępstwie kmieci. A. Podraza, Jakub Kazimierz Haur pisarz rolniczy z XVII wieku, Studium z dziejów polskiej literatury rolniczej, Wrocław-Warszawa-Kraków 1961, s. 60.

100 Oceniano ich negatywnie, ponieważ posiadali małe gospodarstwa i po wypełnieniu pańszczyzny mieli zbyt wiele wolnego czasu. Ibidem, s. 59-60.

101 Obszerniejsze informacje na temat struktury zawodowej i podziałów w stanie kmiecym na obszarze województwa łęczyckiego, ale nie tylko, można znaleźć w pracy B. Baranowskiego, op. cit., s. 48-52, 55-57.

102 APŁ, Arch. K. Wal., t. IV, d. 15. 
$\vec{\sigma}$
$\overrightarrow{0}$
$\stackrel{0}{\sigma}$
$\stackrel{0}{\sigma}$

它

\begin{tabular}{|c|c|c|c|c|c|}
\hline \multirow{4}{*}{$\underset{\underset{N}{N}}{\stackrel{\infty}{N}}$} & نه & ָे & $\stackrel{m}{\rightarrow}$ & $\stackrel{\text { }}{\mathrm{N}}$ & ம் \\
\hline & نَّه & $\mathrm{N}$ & 10 & $\wedge$ & $\stackrel{\Xi}{\sim}$ \\
\hline & $\dot{\theta}$ & $a$ & $\infty$ & $a$ & $\vec{\sim}$ \\
\hline & $\begin{array}{l}3 \\
\dot{d}\end{array}$ & $\stackrel{\cong}{\simeq}$ & เ) & $\wedge$ & $\stackrel{+}{\sim}$ \\
\hline \multirow{4}{*}{ 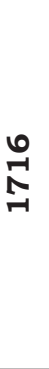 } & نَّه & $\stackrel{10}{\rightarrow}$ & 0 & $\exists$ & లె \\
\hline & $\dot{\sim}$ & เ & - & $\infty$ & $a$ \\
\hline & $\dot{n}$ & 10 & เ) & $-r$ & $\exists$ \\
\hline & $\begin{array}{l}\overrightarrow{3} \\
\dot{0}\end{array}$ & L & & $\wedge$ & $\stackrel{\sim}{\sim}$ \\
\hline \multirow{4}{*}{ סิ } & نَ & $\vec{N}$ & $\stackrel{\mathscr{N}}{\sim}$ & $\underset{\exists}{ \pm}$ & 8 \\
\hline & نص & $\sim$ & $a$ & N & $\stackrel{m}{\rightarrow}$ \\
\hline & $\dot{\theta}$ & m & 욱 & N & $\stackrel{\llcorner}{\sim}$ \\
\hline & 3 & $\stackrel{0}{-}$ & 0 & $\stackrel{\circ}{-1}$ & ले \\
\hline \multirow{4}{*}{ 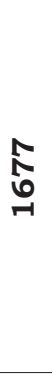 } & 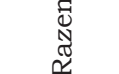 & ণ & $\bumpeq$ & $\stackrel{ \pm}{\leftrightarrows}$ & in \\
\hline & \& & N & $a$ & 1 & $\exists$ \\
\hline & 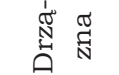 & t & เ & M & $\stackrel{\sim}{\sim}$ \\
\hline & 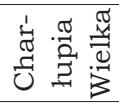 & $\underset{\sim}{+}$ & $m$ & ન & $\stackrel{\infty}{\sim}$ \\
\hline 菅 & & لئّ & 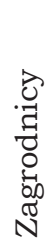 & 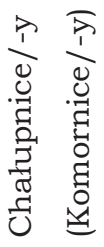 & 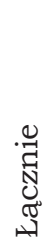 \\
\hline$\dot{\text { خ }}$ & & $\dot{-i}$ & $\dot{i}$ & $\dot{m}$ & $\dot{\sigma}$ \\
\hline
\end{tabular}


Dzieje i obraz majętności charłupskiej... 105

\begin{tabular}{|c|c|c|c|c|c|}
\hline \multirow{4}{*}{ N } & نه & $\vec{N}$ & $\widehat{N}$ & ウे & $\stackrel{\sim}{\infty}$ \\
\hline & نهم & $\sigma$ & 0 & 10 & 늠 \\
\hline & $\dot{\theta}$ & $\wedge$ & 0 & $\Rightarrow$ & $\stackrel{+}{\sim}$ \\
\hline & चं & $\stackrel{-}{-1}$ & $\stackrel{10}{\rightarrow}$ & $\stackrel{\infty}{-}$ & $\stackrel{\mathscr{P}}{+}$ \\
\hline \multirow{4}{*}{ 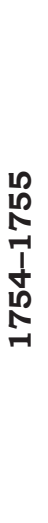 } & $\dot{~}$ & $\stackrel{\text { ণ }}{ }$ & $\frac{\stackrel{i}{N}}{\vec{N}}$ & $\stackrel{\stackrel{L}{N}}{\stackrel{D}{O}}$ & $\stackrel{L}{\varrho}$ \\
\hline & نهم & $\sigma$ & $\wedge$ & $\stackrel{\infty}{\stackrel{\infty}{\circ}}$ & 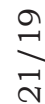 \\
\hline & $\dot{\theta}$ & 0 & 0 & $\frac{0}{10}$ & $\stackrel{\infty}{\stackrel{\infty}{-}}$ \\
\hline & $\begin{array}{l}\overrightarrow{3} \\
\dot{0}\end{array}$ & $\stackrel{ }{-}$ & $\stackrel{\wedge}{\infty}$ & $\underset{\sim}{\stackrel{I}{a}}$ & 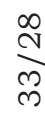 \\
\hline \multirow{4}{*}{ 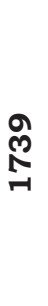 } & نهم & $\stackrel{\infty}{\rightarrow}$ & in & $\stackrel{ }{\sim}$ & $\stackrel{m}{m}$ \\
\hline & نَ & N & $\neg$ & N & เn \\
\hline & $\dot{\theta}$ & 0 & $\neg$ & $\sim$ & $a$ \\
\hline & $\dot{d} 3$ & 윽 & m & 0 & $\stackrel{\sim}{\sim}$ \\
\hline \multirow{4}{*}{ స్ల } & نهم & ָे & $\stackrel{\bullet}{-}$ & $\stackrel{\Xi}{\leftrightarrows}$ & กี \\
\hline & نه & $\sim$ & 0 & 1 & $\infty$ \\
\hline & $\dot{\theta}$ & $a$ & $\nabla$ & 0 & $\stackrel{\sigma}{\sim}$ \\
\hline & $\dot{0}$ & $\underset{\Im}{ }$ & 6 & $\infty$ & $\stackrel{\bullet}{N}$ \\
\hline 范 & & 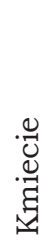 & 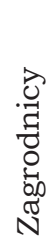 & 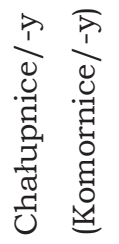 & 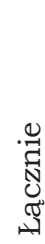 \\
\hline خُ & & $\dot{r}$ & $\dot{i}$ & $\dot{m}$ & $\dot{\sigma}$ \\
\hline
\end{tabular}


Natomiast w Drząnach zabrano po trzech kmieci i zagrodników oraz pięciu chałupników, a do tego wykorzystywano pozostałych do pracy, aż pod Szadkiem. Część z nich uciekła, nie chcąc płacić podatków na rzecz odpowiedzialnego za to W. Krąkowskiego ${ }^{103}$. W Rowach chłopów bito i obciażano wysokimi należnościami finansowymi, co doprowadziło do ucieczki sześciu chałupników. Poza tym S. Kamocki zabrał czterech kmieci i dziewięciu zagrodników. Odpowiadał również za wycinanie drzew z lasów charłupskich, aby w swoich dobrach budować domy. W transporcie korzystał $z$ jednego $z$ młynarzy, mieszkającego w majętności. Przedmiotem rabunkowej gospodarki stały się również zwierzęta. Konie jako łup trafiły w ręce Kałmuków. Bydło zdechło od zarazy, a kilka zarażonych sztuk S. Kamocki kazał sprzedać Żydom z Łasku za 46 złp. Dopełnieniem obrazu zniszczenia były świadectwa dwóch zagrodników, którzy stracili po cztery woły i trzy konie, a jeden $z$ nich jeszcze 80 owiec, świnie oraz zboże przeznaczone do siewu ${ }^{104}$.

Według spisu $z 1716 \mathrm{r}$. prawie połowa poddanych $z$ całej majętności zniknęła w tym w Charłupi Wielkiej - było to ponad $2 / 3$ spośród kmieci. Prowizorycznym rozwiązaniem tego problemu było przekazanie $\mathrm{w}$ ręce półrolnika ${ }^{105}$ i niedawno osiedlonego chłopa gospodarstw kmiecych, ponieważ nie było żadnego zagrodnika, a jedynie kilku komorników i komornic oraz karczmarz i włodarz. Warto podkreślić, o czym w następnych inwentarzach nigdy już nie pisano, że w pięciu domach zamieszkiwała szlachta: w dwu rodzina Baybuzów oraz Włostowscy, Wołoszewicze i pani Osędowska ${ }^{106}$. Sytuacja pozostałych wsi była w miarę stabilna. Choć w Rowach pozostał jeden zagrodnik $z$ dziewięciu, to zwiększyła się liczba kmieci. Podobnie było w Drząnach, gdzie brakowało połowy zagrodników oraz kmieci. W tej sytuacji osadzono kolejnych trzech chłopów na kmiecych rolach i podobnie postąpiono $z$ czterema zagrodnikami.

W tym okresie obok zwierząt i ludzi w złym stanie były budynki mieszkalne oraz gospodarcze, np. w Drzaznie należało wyremontować cztery $z$ dziewięciu zamieszkałych chałup. Podobnie sytuacja wyglądała ze stodołami. Poza tym był wolny plac bez zabudo-

103 Pani Obiedzińska, siostra braci Krakowskich, zabrała zwierzęta: trzy krowy, wołu, cielę, ale również pług, radło czy zasiewki. Ibidem, t. IV, d. 14, 16.

${ }^{104}$ Ibidem, t. IV, d. 12

105 Grupa półrolników powstała, ponieważ kmiecie nie byli w stanie wywiązać się ze swoich należności wobec dworu. A. Podraza, op. cit., s. 58-59.

${ }^{106}$ APŁ, Arch. K. Wal., t. IV, d. 13. 
wań, pusta karczma i dwie chałupy, jedna rozpadajacca się bez stodoły oraz druga niedawno wybudowana, ale niezamieszkała ${ }^{107}$. Niewiele lepiej było w Rowach, gdzie na 10 domów połowa znajdowała się w złym stanie, a trzy były niezamieszkane, natomiast jedna $z$ komornic mieszkała w „budzie”. Nie lepiej wygladało to w przypadku budynków gospodarczych, np. stodół czy opuszczonej i zniszczonej karczmy ${ }^{108}$.

Fatalny stan majętności charłupskiej znowu wymagał zaangażowania finansowego i uwagi tym razem ze strony J. Walewskiego. Po 1716 r. uczynił sporo, aby owe dobra podnieść $z$ gospodarczej zapaści. Potwierdzeniem tego było odbudowanie zniszczonych domów z zabudowaniami oraz podniesienie liczby poddanych. W $1728 \mathrm{r}$. cała majętność liczyła prawie tylu mieszkańców, ile w 1691 r., ale w Charłupi Wielkiej było ich mniej, natomiast w pozostałych wsiach więcej. Niewatpliwie istotnym czynnikiem, stojącym za odbudową owych dóbr, musiał być fakt, że kasztelan rozpierski J. Walewski posiadał w tym samym czasie inne nieruchomości, co pozwalało np. na przenoszenie poddanych. Tym być może należy tłumaczyć niewielki spadek zamieszkałych w majętności charłupskiej w 1732 r., przy czym największy był w Rowach. Niekorzystne były również działania wojenne związane $z$ walką o tron po śmierci Augusta II, co potwierdzała skarga F. Walewskiego opisujacca straty, jakie poczyniło wojsko w jego dobrach.

W kolejnych latach rosła liczba mieszkańców w majętności charłupskiej, przy czym zauważalne były różnice w rozkładzie owego wzrostu. Jeśli chodziło o kmieci, to w Charłupi Wielkiej w latach 1728-1777 niewiele się zmieniało, ponieważ ich liczba wahała się od 10 do 12. Inaczej wyglądało to w Drzaznach, gdzie w latach 1728-1732 mieszkało dziewięciu kmieci, później ich liczba spadła do sześciu. W Rowach w 1716 r. wymieniono ich pięciu, a po tym roku było ich tylko dwóch i taka sytuacja istniała do 1754 r., gdy odnotowano czterech. W przypadku pozostałych grup pracujacych na roli, jak zagrodnicy ${ }^{109}$, chałupnicy i komornicy ${ }^{110}$ te wahania były jeszcze większe. Zapewne można to tłumaczyć mniejszymi

\footnotetext{
107 Ibidem, t. IV, d. 11.

108 Ibidem, t. IV, d. 11, 12, 14.

109 W Charłupi Wielkiej mieszkało w tym okresie od trzech do piętnastu zagrodników, w Drząznej od jednego do sześciu i w Rowach od jednego do siedmiu.

${ }^{110}$ W Charłupi Wielkiej żyło od sześciu do osiemnastu, a w Drząznej od dwóch do jedenastu. W 1732 r. w Rowach nie było żadnego komornika, natomiast w 1754 r. było ich dziesięciu.
} 
ograniczeniami w przenoszeniu poddanych $z$ jednej wsi do drugiej. Tego rodzaju zjawisko występowało, co potwierdzaja informacje pochodzace $z$ dwu następujacych po sobie inwentarzy $z$ lat 1754 i 1755. Okazało się, że w Charłupi Wielkiej, w późniejszym spisie nie wymieniono zagrodnika i czterech komorników. Podobne przypadki były również w pozostałych wsiach.

Natomiast biorąc pod uwagę ogólną liczbę mieszkańców majętności, to w latach 1754-1777 ich liczba powoli rosła i osiągnęła nienotowany wcześniej poziom. Potwierdzają to również dodatkowe źródła pochodzace $z$ końca XVIII w. Na podstawie rejestru ludności, jaki przygotowano w wyniku ustaleń Sejmu Czteroletniego w 1789 r., wiadomo, że żyło w tych dobrach 486 osób. Z kolejnego spisu, dokonanego przez Prusaków po zajęciu województwa sieradzkiego w 1793 r., dowiadujemy się o 379 mieszkańcach samej Charłupi Wielkiej. Co ważne, spisy te podaja również podziały na kategorie zawodowe, ale nie wyróżniano już kmieci i zagrodników, lecz jedna grupę gospodarzy. W 1789 r. należały do niej 103 osoby, w tym 53 mężczyzn. Poza tym wyróżniono komorników i komornice, tych było odpowiednio 11 i 20. Nie zaszła więc poważna zmiana, jeśli weźmie się pod uwage dane $z 1777$ r., w których suma kmieci i zagrodników ze wszystkich dóbr wynosiła 48, a komorników 34. Natomiast w 1793 r. jedynie w Charłupi Wielkiej mieszkało 36 gospodarzy, 10 komorników i 31 komornic. W 1789 r podano również liczbę dymów - 70. Najwięcej $z$ nich, bo 46 należało do gospodarzy ${ }^{111}$.

W XVIII w. kmiecie, podobnie jak w poprzednich stuleciach, byli najlepiej uposażoną grupa wśród stanu chłopskiego. Niewątpliwie ich liczba, zamożność i możliwości ekonomiczne, dotyczące zagospodarowania swoich gospodarstw, były podstawa dochodowości w dobrach szlacheckich. Pod tym względem dobra należące do Walewskich nie odbiegały od przedstawionego schematu. Uposażeni w największe pod względem obszaru gospodarstwa kmiecie, choć nie znamy ich wielkości w przypadku majętności charłupskiej, posiadali również inwentarz żywy i narzędzia do pracy na roli.

$\mathrm{Na}$ podstawie informacji $z$ inwentarzy można prześledzić wahania posiadania przez kmieci zwierząt używanych w gospodarstwie chłopskim. W 1677 r. w Charłupi Wielkiej prawie 75\% z nich miało po cztery woły, ponad połowa po dwa konie i tylko w przypadku

${ }^{111}$ APŁ, Arch. K. Wal., t. IV, d. 223, 231. 
jednego nie było żadnych zwierząt pociagowych. Pozostali w Drzaznach i Rowach mieli po cztery woły, a połowa $z$ nich jeszcze po dwa konie i tylko w jednym przypadku nie posiadano konia ${ }^{112}$. Warto podkreślić, że kilkanaście lat później, w 1691 r., każdy z kmieci miał po cztery woły, a ponad $85 \% \mathrm{z}$ nich miało konia, przy tym prawie połowa $z$ nich posiadała po dwa. W 90\% gospodarstwach kmiecych wymieniano krowę i w jednym przypadku były ich dwie. Ponadto u nieco ponad $40 \% \mathrm{z}$ nich znajdowały się świnie ${ }^{113}$. Poza zwierzętami pociagowymi i domowymi kmiecie posiadali w ramach wyposażenia wozy, pługi, kosy, sierpy, zydle, radła czy inne narzędzia żelazne, które były własnością szlachecką.

$\mathrm{W}$ zamian za użytkowanie gospodarstw kmiecie $\mathrm{w}$ majętności charłupskiej musieli pracować na pańskim polu przez cały tydzień oprócz poniedziałku, co potwierdzano w kolejnych inwentarzach. Jednak w okresie żniw, czyli od momentu, gdy zaczynano kosić łakki, nie mieli owego wolnego dnia. W XVIII w. doszło do pewnych zmian, o czym świadczył zapis z 1728 r., w którym kmiecie mieli pracować na pańskim polu od 13 lipca do 29 września, we dwie osoby i ze sprzężajem, korzystając $z$ posiadanych wołów czy koni. Niewiele to odbiegało od wysokości pańszczyzny obowiązującej w dobrach królewskich ${ }^{114}$. Warto podkreślić, że tylko w $1677 \mathrm{r}$. ponad połowa kmieci płaciła za robociznę, a nie ją wykonywała.

Kolejnym istotnym ciężarem był obowiązek płacenia czynszu, którego wysokość w majętności charłupskiej była zmienna i uzależniona od wsi. W Charłupi Wielkiej został on ustalony na 3 złp. 6 gr (2 grzywny) i nie zmienił się do końca XVII stulecia. W pierwszej połowie następnego wieku owe stawki pozostawały niezmienne, ale w 1754 r. nakazano płacić 3 złp., co utrzymało się w następnych latach. Niższe stawki obowiązywały w Drząnach - 2 złp. 12 gr do 1777 r. W przypadku wsi Rowy to z 1 złp. 18 gr. Stawka czynszu wzrosła do 2 złp. w 1732 r., a następnie do 2 złp. 15 gr w 1754 r. ${ }^{115}$ Innym obciążeniem o charakterze pieniężnym był pobór w wysokości

112 Co ważne, pięciu kmieci nie miało zboża na zasiewek. W jednym przypadku wydano ziarno na oziminę oraz kazano siać jarzynę. AGAD, SGRel. 45, k. 632-632v.

113 Ibidem, 55 cz. 1, k. 417-419v.

114 Było to pięć-szęść dni w tygodniu, ale w dobrach szlacheckich mogło być więcej. E. Trzyna, Wtórne poddaństwo, [w:] Historia chłopów polskich, t. I (Do upadku Rzeczypospolitej szlacheckiej), red. S. Inglot, Warszawa 1970, s. 310.

115 Najwyższa stawka w Charłupi Wielkiej pojawiła się w 1732 r. W Rowach jedynie w 1754 r. podano, że kmiecie mieli płacić po 2 złp. 15 gr. 
6 gr i szelaga, który płacili tylko kmiecie $z$ Charłupi Wielkiej $\mathrm{w}$ latach 1677-1691 ${ }^{116}$. Natomiast należności regulowane w naturze były uzależnione od konkretnej wsi. Każdy $z$ kmieci $z$ Charłupi Wielkiej i Rowów powinien był dostarczyć po dwa korce żyta i owsa, natomiast ci z Drząznej po jednym. Wszyscy mieli dawać po dwa kapłony i kury oraz 30 jaj $z$ wyjątkiem tych $z$ Drząznej.

Pozostało jeszcze ostatnie $z$ zobowiąań, czyli powinności wobec dworu. Od 1691 r. się one nie zmieniły - należało do nich przędzenie jednej sztuki przędzy, ale w 1732 r. zaproponowano, żeby zamiast tego można było płacić 1 złp. Były również inne, jak skubanie chmielu czy prace przy kapuście i rzepie. Na kmieciach, na zmianę $z$ młynarzami, ciążyło zobowiązanie, aby raz w roku jeździli oni do Wieliczki po sól. Walewscy zastrzegli jednak, że nie musieli oni wysyłać kogoś spośród siebie, ponieważ wystarczyło, by zebrali pieniądze na ten cel i przekazali je do dworu. Tylko raz, w 1755 r., wymieniono obowiązek stróży w czasie świąt, jaki spadł na kmieci Z wsi Rowy ${ }^{117}$.

Zagrodnicy stanowili kolejna grupę ze stanu kmiecego wymienianą we wszystkich inwentarzach. Podobnie jak to było $z$ kmieciami, nie wiadomo, jaki areał ziemi tworzył gospodarstwo zagrodnika, ale było one mniejsze od kmiecego. Ponadto mniej było zwierząt w zagrodzie oraz narzędzi, jakie wykorzystywano do pracy w polu. W niektórych przypadkach część $z$ zagrodników zajmowała się innymi rzeczami, tak jak wymienieni w pierwszym $z$ inwentarzy kuśnierz czy karczmarz, żyjący w Charłupi Wielkiej. Obaj musieli odpracować 12 dni w okresie żniw, pierwszy $z$ nich miał pracować dla dworu, a drugi szynkować i ponadto pilnować zbóż, łąk oraz przeganiać szkodników. Podobnie w Drząznach był zagrodnik zajmujący się szynkowaniem piwa, a w Rowach karczmarz. Z kolei do obowiązków innego $z$ zagrodników należało pilnowanie łąki. Pozostali byli zobowiąani do pracy od 23 kwietnia do 15 października przez trzy dni w tygodniu, a w pozostałym okresie jedynie dwa dni. Płacili po 6 groszy czynszu i co kwartał na rzecz poboru „pół trzecia groszy", czyli 3 denary. Co ciekawe, ponad połowa z zagrodników żyjących w całej majętności charłupskiej mieszkała we wsi Rowy ${ }^{118}$.

W 1691 r. w 11 przypadkach zagrodnicy musieli płacić 6 groszy czynszu i pracować trzy dni w tygodniu na pańskim polu.

\footnotetext{
116 AGAD, SGRel. 55 cz. 1, k. 417-419v.

117 APŁ, Arch. K. Wal., t. IV, d. 35, 43, 88, 93; t. VII, s. 225-239.

118 AGAD, SGRel. 45, k. 632-632v.
} 
Poza tym sześciu zagrodników mieszkających w Charłupi Wielkiej miało wyławiać ryby i wycierać sadze. Na kolejnych 10 , żyjacych w Rowach i Drząnach, ciążył obowiązek tkania płótna, którego każdy miał dostarczyć 6 łokci. W Charłupi Wielkiej mieszkał kuśnierz, niemający żadnych dodatkowych obciążen. Karczmarz, któremu naprawiono stajnię, miał szynkować piwo i pańska gorzałkę oraz w czasie żniw pracować przez 12 dni. W inwentarzu pojawił się Mateusz Oganiacz, do którego obowiązków należało pilnowanie, by nie było szkody w zbożach czy łąkach. Poza tym miał pracować trzy dni w tygodniu po uprzątnięciu zboża $z$ pól oraz siana $z$ łąk. Był również leśnik Maciej Tytuch, z obowiązkiem pilnowania lasu. W Drząznach natomiast mieszkał Kazimierz Swiec, przy którym podano, że miał płacić 15 złp. czynszu. Była to stawka bardzo wysoka i nie wiadomo, jakie ciążyły na nim zadania, które wymagały wypłacania takiej kwoty, gdy w pozostałych przypadkach było to kilka groszy. Wyróżniało go, jak i kolejnych sześciu zagrodników, to, że w czasie żniw mieli pracować po 12 dni w tygodniu na pańskim polu. Tak miał robić m.in. karczmarz czy leśnik w Drząznej oraz pozostali mieszkający w Rowach, o których zawodach, oprócz leśnika Tomasza, nic nie wiadomo ${ }^{119}$. Podobne obciążenia dotyczyły np. komorników wymienionych w 1728 r.

W XVIII w. sytuacja zagrodników w majętności charłupskiej uległa zmianie. Pod względem uposażenia była to grupa uboższa od kmieci i tylko niektórzy $z$ nich posiadali woły. Nadal jednak mieli odrabiać pańszczyznę pieszą według wymienionych wcześniej warunków. Jednak w inwentarzu z 1732 r. zmieniono czas pracy, który od tej pory pokrywał się $z$ terminem, w jakim pracowali kmiecie, czyli od 13 lipca do 29 września, przez trzy dni w tygodniu. Zagrodnicy byli również obciążeni stróżą. Poza tym mogli pracować przy ważeniu piwa i tym, którzy tak robili, odejmowano dwa dni pańszczyzny ${ }^{120}$.

Najbardziej uboga grupa, jaką wymieniano w inwentarzach, byli chałupnicy oraz komornicy i komornice. W latach 1677-1691 liczba tych ostatnich nie zmieniła się zbytnio, natomiast po raz pierwszy wymieniono trzech chałupników, którzy mieli przebywać w Charłupi Wielkiej, w 1691 r. Nic nie wiadomo o ich domostwach czy majątku ruchomym. W kwestii zobowiązań, w 1677 r. tylko niejaki Wacek z Charłupi Wielkiej pracował dzień w tygodniu. W kolejnym

119 Ibidem, 55 cz. 1, k. 418-419v.

120 APŁ, Arch. K. Wal., t. IV, d. 35, 43, 88, 93. 
inwentarzu podano, że taki obowiązek ciążył na wszystkich. Poza tym musieli prząść pół sztuki przędzy, prać, strzyc owce oraz łowić ryby przy spuszczaniu wody ze stawów ${ }^{121}$. Warunki nie zmieniły się w następnym stuleciu, a w 1728 r. wymieniono trzech komorników, którzy mieli pracować 12 dni przy ogrodzie oraz jako słudzy lub rybacy. Płacili $z$ tego 15 złp. czynszu rocznie. Cztery lata później tyle samo dni pracowali przy żniwach czy w innych miejscach, gdzie byli potrzebni czterej komornicy. Natomiast komornice miały tkać płótno, co zwalniało je ze służby. W 1754 r. wprowadzono zasadę, że połowę swoich wyrobów przekazywały właścicielowi, a druga dzierżawcy ${ }^{122}$.

Poza opisanymi grupami w majętności charłupskiej żyli również młynarze i inni rzemieślnicy blisko zwiąani $z$ funkcjonowaniem wsi. Pierwsi $z$ wymienionych przewijali się we wszystkich inwentarzach. W latach 1677-1691 można było zaobserwować tendencję wzrostowa $z$ sześciu do dziewięciu młynarzy. W 1677 r. połowa $z$ wymienionych miała pracować na pańskim polu przez sześć dni $\mathrm{w}$ tygodniu $z$ wolnym poniedziałkiem. $Z$ tego czterech miało płacić czynsz w wysokości od 4 złp. 24 gr (3 grzywny) do 19 złp. 6 gr (12 grzywien). Poza tym na pięciu ciążył obowiązek karmienia wieprzy (od jednego do trzech) i dostarczenia po dwa kapłony. Każdy młynarz musiał płacić również 4 grosze i szelaga, a od młyna płacono 1 złp. 18 gr (1 grzywnę). Istniał obowiązek, podobnie jak w przypadku kmieci, zaopatrywania majętności charłupskiej w sól wielicka i 1677 r. przypadł on na niejakiego Pawłowskiego, który musiał po nia pojechać123.

W 1691 r. młynarze mieli różne stawki czynszu, ale wszyscy musieli pracować pięć dni w tygodniu. $Z$ tego grona dwóch miało przekazywać po 20 korcy żyta i karmić trzy wieprze. Poza tym powinni mleć pańskie zboże oraz słody oraz przewozić je własnym transportem do dworu. Powinni wydawać bez żadnego pomiaru słód jaglany. Kolejni trzej płacili po 19 złp. 6 gr czynszu, dwaj po 9 złp. 18 gr i kolejni dwaj po 4 złp. 24 gr. Czterech $z$ siedmiu miało obowiązek hodować po dwa wieprze. Jednego miał wyhodować niejaki Tytuch, pozostali byli $z$ tego zwolnieni. Poza tym po kapłonie przekazywali trzej młynarze. Nadal ciążył obowiązek przywożenia

121 AGAD, SGRel. 55 cz. 1, k. 418v-419v.

$122 \mathrm{Za}$ każdą sztukę materiału miały być zwolnione z 12 dni. APŁ, Arch. K. Wal., t. IV, d. 35, 43, 88; t. VII, s. 225-239.

123 AGAD, SGRel. 45, k. 632v-633. 
soli $z$ Wieliczki, ale na zmianę $z$ kmieciami. Zastrzeżono, aby młynarze swoja pracę wykonywali własnymi siekierami, młócili swoimi narzędziami, zwozili zboże lub siano $z$ pola swoim transportem. Poza tym pięciu $z$ nich miało płacić jeden pobór w postaci 4 gr i szelaga. Być może zagrodnik Maciej Młynarz również umiał wykonywać ten zawód, o czym mógł świadczyć jego przydomek, ale nie mógł go praktykować ${ }^{124}$.

Wspomniane wcześniej zniszczenia na początku XVIII w. dotknęły mocno również młynarzy. W 1716 r. było siedem czynnych młynów. Poza tym, o czym świadczyło obciążenie w postaci wyhodowania dwóch wieprzów rocznie, zawód ten wykonywał jeden $z$ chłopów, który przez sześć lat mieszkał we młynie. Dwanaście lat później, dzięki nakładom J. Walewskiego, liczba młynów wzrosła do 10. Tyle też działało w majętności charłupskiej, aż do drugiego rozbioru Rzeczypospolitej, z niewielkimi wyjątkami. Tylko w 1754 r. wymieniono ich 11, natomiast w $1777 \mathrm{r}$. osiem. Nie wiadomo, jaka była przyczyna takiej sytuacji, natomiast przez cały XVIII w. liczba młynów nigdy nie osiagnęła 13, a taką wartość podano w zeznaniach z $1716 \mathrm{r}$., gdy szacowano straty w majętności charłupskiej ${ }^{125}$. W tym okresie $w$ inwentarzach podawano mniej informacji o zobowiazaniach młynarzy, jak to było wcześniej. Stawki czynszu wahały się od 4 złp. 24 gr do 19 złp. 6 gr w 1728 r. ${ }^{126}$, czy od 3 do 19 złp., a jeden nawet 80 złp. według opisów z lat 1754-1755. Większość z młynarzy miała odpracowywać pańszczyznę przez sześć dni, ale w pojedynczych przypadkach ustalano od dwóch do 12 dni. Na wszystkich ciążył również „wieprzowy pieniądz", czyli płacenie w dwu ratach co roku po 48 złp. w zamian za wcześniejszy obowiązek hodowli dwóch wieprzów. Poza tym ośmiu miało dostarczyć po kapłonie. Należy wspomnieć, że część z młynarzy posiadało konie i woły ${ }^{127}$.

Wspomniani już przedstawiciele innych grup zawodowych zostali wliczeni do grona zagrodników w dwu pierwszych inwentarzach. Natomiast w XVIII w. wymieniano ich oddzielnie i do nich zaliczaja się karczmarze, w 1716 r. był jeden, 12 lat później trzech i tylu też wymienia się w 1754 r. Od tego momentu ich liczba spadała.

${ }^{124}$ Ibidem, 55 cz. 1, k. 419v-420.

125 APŁ, Arch. K. Wal., t. IV, d. 13, 15, 35, 43, 55, 88, 93; t. VII, s. 225-239.

126 Ibidem, t. IV, d. 35.

127 Wpłacenie owych 48 złp. należało uiścić w ratach, których terminy przypadały 24 VI i 24 XII każdego roku. Ibidem, t. IV, d. 88, 93. 
Jednak w spisach ludności z lat 1789-1793 wymienia się karczmarza i dodatkowo trzech szynkarzy. Jedynym obowiazkiem, jaki musieli pełnić na rzecz właściciela, była praca przez $12 \mathrm{dni}$ w polu podczas żniw ${ }^{128}$.

W majętności charłupskiej mieszkali ponadto leśnicy, kowale, pilarz, szewcy i krawcy. W spisie ludności z 1789 r. wymieniono pięciu rzemieślników, nie podając ich profesji. W kolejnym natomiast byli płóciennicy, cieśla oraz kucharz. Dodatkowo pracowało jeszcze w tych dobrach 54 osoby jako służący, czeladnik i dwóch "gosemnych". W pierwszym spisie uwzględniono także 16 żebraków, w tym pięciu mężczyzn i 11 kobiet $^{129}$.

Przedstawiony obraz szlacheckiego majątku powstał dzięki zachowanym inwentarzom Charłupi Wielkiej, Drząny i Rowów. Ten rodzaj źródeł dostarczył wielu informacji na temat funkcjonowania prywatnych dóbr położonych w województwie sieradzkim, w szczególności losów dworu i jego otoczenia na przestrzeni stuleci. Kolejne opisy przedstawiajace stan siedziby Walewskich wraz $z$ wyposażeniem pozwoliły na śledzenie zmian w bryle samego budynku przez prawie całe stulecie. Lektura inwentarzy utwierdza we wniosku, że obraz dworu był na początku o wiele skromniejszy, łącznie $z$ wyposażeniem, niż ten zawarty w ostatnim $z$ nich, co nie odbiegało od ustaleń literatury przedmiotu $\mathrm{w}$ odniesieniu do opisów dworów w XVIII w. ${ }^{130}$ Potwierdza to stan i materiały, $z$ jakich były zrobione okna, drzwi czy zamki. Dzięki nim można zauważyć regres $z$ początku XVIII stulecia. Na tej podstawie można zaobserwować, że dopiero w latach pięćdziesiątych XVIII w. osiagnnięto poziom sprzed wojny północnej, a opis z 1777 r. ukazywał jeszcze wyższy standard. Należy również zauważyć, że drewniany dwór zbudowany na początku XVIII w. istniał do $1777 \mathrm{r}$., jeśli nie dłużej. Był przebudowywany, zmieniało się również jego najbliższe otoczenie, gdzie znajdowały się zabudowania gospodarcze potrzebne do funkcjonowania dworu i działalności rolniczej. Różnorodność i liczba tego rodzaju budynków wskazuje na poziom rozwoju gospodarczego, co potwierdza również to, że oprócz koni, krów, kur czy świń Walewscy byli nastawieni na produkcję wełny czy innych korzyści płynących z utrzymywania stada owiec. Poza tym był również ogród czy stawy, w których hodowano ryby. Stąd

128 Ibidem, t. IV, d. 13, 35, 43, 88, 93, 223, 231.

129 Ibidem, t. IV, d. 223, 231.

130 B. Baranowski, op. cit., s. 100-102. 
w przypadku Charłupi Wielkiej można mówić o kompleksie budynków, a nie jedynie rezydencji, w której zamieszkiwał szlachcic wraz $z$ rodziną.

Kryzys, jaki dotkną majętność charłupską w początkach XVIII w., wyrządził wiele złego na kilku płaszczyznach. Poza zniszczeniami dworu dotknął zabudowania gospodarcze, odbił się także na zaludnieniu. Właśnie na przykładzie tych dóbr widać wyraźnie, ile było potrzeba sił, środków i czasu, aby przywrócić stan, jaki istniał pod koniec XVII w. Niewątpliwie do zasług kolejnych przedstawicieli rodu Walewskich należało to, że byli oni w stanie podnieść dobra $z$ kryzysu wraz $z$ dochodem, jaki $z$ nich osiagali. Jednak owe inwestycje skutkowały zadłużeniem dóbr. Niewątpliwie ważne było to, że cała majętność przez większość stulecia znajdowała się w rękach jednej rodziny, przechodzac $z$ ojca na syna jako dobra dziedziczne. Choć w tym okresie były wypuszczane różnym osobom, to jednak nie doszło już do takiej sytuacji, jaka zaistniała na początku XVIII w.

\section{Bibliografia}

\section{$\dot{Z}_{\text {RÓDEA ARChIWALNE }}$}

Archiwum Główne Akt Dawnych w Warszawie [AGAD]

Księgi sieradzkie grodzkie inskrypcje [SGInscr.] 184, 186, 188, 190, 191, 201-205, 207, 209, 217, 219, 225, 226, 228, 230, 234.

Księgi sieradzkie grodzkie relacje [SGRel.] 41, 45, 55 cz. 1, 61, 66, 92, 188.

Archiwum Państwowe w Łodzi [APŁ]

Archiwum Kazimierza Walewskiego $z$ Tubądzina [Arch. K. Wal.], t. I-IV, VII, VIII, XXXIX, XLI, XLIII, XLV.

Biblioteka Kórnicka PAN

rkps 11267 (S. Leitgeber, Walewscy herbu Kolumna, maszynopis).

\section{$\dot{Z}_{\text {RÓDEA DRUKOWANE }}$}

Kitowicz J., Opis obyczajów za Augusta III, Warszawa 1985.

Niesiecki K., Herbarz Polski, t. IX, Lipsk 1842.

\section{Opracowania}

Atlas historyczny Polski, t. V (Województwo sieradzkie i województwo łęczyckie w drugiej połowie XVI wieku), red. H. Rutkowski, Warszawa 1998. 
Baranowski B., Gospodarstwo chłopskie i folwarczne we wschodniej Wielkopolsce w XVIII wieku, Warszawa 1958.

Ciesielski T., Armia koronna w czasach Augusta III, Warszawa 2009.

Gloger Z., Budownictwo drzewne $i$ wyroby $z$ drzewa $w$ dawnej Polsce, t. I-II, Warszawa 1907.

Gloger Z., Encyklopedia staropolska ilustrowana, t. I, Warszawa 1900.

Kajzer L., $Z$ badań nad budownictwem rezydencjalno-obronnym ziemi łęczyckiej i sieradzkiej w XVI wieku, „Kwartalnik Architektury i Urbanistyki” 1979, t. XXIV, z. 4, s. 373-382.

Klimek B., Zabytkowa stolarka okienna i drzwiowa drewnianych chałup i zabudowy gospodarskiej na Lubelszczyźnie - wybrane przykłady z Muzeum Wsi Lubelskiej, „Budownictwo i Architektura” 2015, t. XIV (III), s. 195-207.

Kobierecki M., Walewscy herbu Kolumna w XVII-XVIII wieku. Genealogia. Majętność. Działalność publiczna, Łódź 2008.

Łoziński W., Życie polskie w dawnych wiekach (wiek XVI-XVIII), Jerozolima 1946.

Podraza A., Jakub Kazimierz Haur pisarz rolniczy z XVII wieku, Studium z dziejów polskiej literatury rolniczej, Wrocław-Warszawa-Kraków 1961.

Słownik geograficzny Królestwa Polskiego i innych krajów słowiańskich, t. I, red. B. Chlebowski, Warszawa 1880.

Słownik geograficzny Królestwa Polskiego i innych krajów słowiańskich, t. XV, red. B. Chlebowski, J. Krzywicki, Warszawa 1900.

Słownik staropolski, red. S. Urbańczyk, t. VI, z. 2, Wrocław-Warszawa-Kraków 1970.

Słownik staropolski, red. S. Urbańczyk, t. VIII, z. 2, Wrocław 1978.

Szymczak A., Szlachta sieradzka w XV wieku. Magnifici et generosi, Łódź 1998.

Trzyna E., Wtórne poddaństwo, [w:] Historia chłopów polskich, t. I (Do upadku Rzeczypospolitej szlacheckiej), red. S. Inglot, Warszawa 1970, s. 327-336.

Wyczański A., Szlachta polska XVI wieku, Warszawa 2001.

Wyczański A., Uwagi na temat dworu szlacheckiego $w$ Wielkopolsce XVI w., „Kwartalnik Architektury i Urbanistyki" 1979, t. XXIV, z. 4, s. 347-355.

Zajączkowski S., Uwagi nad osadnictwem dawnych ziem łęczyckiej i sieradzkiej (do przełomu XI i XII w.), „Rocznik Łódzki” 1964, t. IX (XII), s. 165-198.

Zajaczkowski S.M., Studia nad wielowioskowa własnościa szlachecka $w$ Łęczyckiem i Sieradzkiem i jej rola $w$ osadnictwie (od końca XIV do połowy XVI w.), „Kwartalnik Historii Kultury Materialnej” 1966, R. XIV, nr 2, s. 179-208.

Zajączkowski S.M., Wielowioskowa własność szlachecka $w$ dawnych ziemiach łęczyckiej $i$ sieradzkiej $w$ drugiej połowie XIII $i w$ XIV w., „Rocznik Łódzki” 1964, t. IX (XII), s. 119-143.

Zajaczkowski S.M., Wielowioskowa własność szlachecka w województwie sieradzkim (XV i pierwsza połowa XVI w.), „Rocznik Łódzki” 1973, t. XVIII (XXI), s. $23-50$.

Zajaczkowski S.M., Własność rycerska $w$ dawnych ziemiach łęczyckiej $i$ sieradzkiej do połowy XIII w., „Rocznik Łódzki” 1961, t. IV (VII), s. 139-169.

Żychliński T., Złota księga szlachty polskiej, t. IV, Poznań 1882. 


\section{History and portrayal of Charłupia Wielka property in hands of the Walewskis, Kolumna court of arms, in the second half of $17^{\text {th }}$ and in $18^{\text {th }}$ century according to the inventory}

\footnotetext{
$\mathrm{T}^{\mathrm{h}}$ he villages of Charłupia Wielka, Rowy and Drzazny constituted the Charłupia Wielka estate, which lay in the Sieradz Voivodeship in the Polish-Lithuanian Commonwealth. Until the $17^{\text {th }}$ century it belonged to the house of Swinkowie, Malscy of the Nałęcz coat of arms and Zapolscy of the Pobóg coat of arms. As a result of marital contracts and legal lawsuits the lands came into the hands of Jan Franciszek Walewski, the pantler of Sieradz and his wife Bogumiła Konstancja of the Zapolscy family. In the $18^{\text {th }}$ century the consecutive members of the Walewscy family of the Column coat of arms were the owners, namely Jan and Franciszek, the castellans of Rosprza as well as Jan Nepomucen, the Grand Standard Bearer of Sieradz. On the basis of the surviving inventories from the end of the $17^{\text {th }}$ and from the $18^{\text {th }}$ centuries one can follow the fortunes of Chartupia Wielka, Rowy and Drzazny. These domains, which thrived in the time of the Sieradz pantler, deteriorated at the beginning of the $18^{\text {th }}$ century due to problems with creditors. The subsequent owners acquired the goods and undertook the repayment of liabilities. Throughout the century they invested in the properties, hence raising their value. Descriptions of the manor and land buildings show how much changed over the years. The manor became the seat of this Walewscy family line, and the variety of buildings showed that apart from farm work income, the owners drew financial gains from sheep farming and horse breeding. An important matter was also populating the goods, which underwent changes. Having overcome the crisis at the beginning of the $18^{\text {th }}$ century, the number of dependent population increased, and so did the income from agricultural production. The fortunes of the Charłupia Wielka estate show how noble properties of the Sieradz Voivodeship tried to rise after the period of destruction of the Northern War as well as how the problem of debts and management was handled in different periods of economic situation.
}

Keywords: inventories of goods in the $18^{\text {th }}$ century, nobility of Sieradz in the $18^{\text {th }}$ century, noble properties. 